\title{
Are Family Firms Good Employers?
}

\author{
Jeroen Neckebrouck \\ Vlerick Business School \\ Ghent University, Belgium \\ Jeroen.Neckebrouck@ vlerick.com \\ William Schulze* \\ David Eccles School of Business \\ University of Utah \\ Salt Lake City, UT 84108 \\ William.Schulze@utah.edu \\ Thomas Zellweger \\ Centre for Family Business \\ University of St Gallen \\ St Gallen, Switzerland \\ Thomas.Zellweger@unisg.ch \\ * Corresponding author \\ June 1, 2017 \\ FINAL VERSION \\ Submitted for publication in
}

The Academy of Management Journal 


\title{
Are Family Firms Good Employers?
}

\begin{abstract}
Are family firms good employers? Anecdotal and empirical evidence suggests they are. Arregle, Hitt, Sirmon, and Very (2007) assert family firms recognize that employees are their life blood and strive to build a talented, motivated, and loyal workforce by investing in employee training (Kachaner, Stalk, \& Bloch, 2012), developing an inclusive work culture (Miller, Le BretonMiller, \& Scholnick, 2008), and by exercising stewardship toward the communities in which they operate (Davis, Schoorman, \& Donaldson, 1997). Miller and Le Breton-Miller (2006: 82) note that family firms are known for "profound investment in employee training, minimum layoff policies, employee participation programs, painstaking staff selection, generous benefits, and miniscule turnover statistics." And while empirical evidence about compensation is mixed, multiple studies propose that family businesses offer greater job security (Allouche \& Amann, 1998; Bassanini, Breda, Caroli, \& Rebérioux, 2013; Carrasco-Hernandez \& Sánchez-Marín, 2007; Reid \& Harris, 2002; Sraer \& Thesmar, 2007). Together, and in line with stewardship perspectives (e.g., Davis et al., 1997; Donaldson \& Davis, 1991), this evidence lends support to the notion that family firms are good employers (Corbetta \& Salvato, 2004; Eddleston \& Kellermanns, 2007; Miller et al., 2008; Pittino, Visintin, Lenger, \& Sternad, 2016).
\end{abstract}


While the claim that family firms are good employers is consistent with stewardship perspectives, it is at odds with earlier studies that document significant personnel-related agency costs within family firms, including perquisites (Schulze, Lubatkin, Dino, \& Buchholtz, 2001; Villalonga \& Amit, 2006), nepotism (Chrisman, Sharma, Steier, \& Chua, 2013; Verbeke \& Kano, 2012), and executive entrenchment (Bertrand \& Schoar, 2006; Volpin, 2002). Research about family firm governance (see Madison, Holt, Kellermanns, \& Ranft (2016) for a review) is also mixed, with some authors suggesting that stewardship behaviors are prevalent (Pearson \& Marler, 2010), while others find that agentic behavior is commonplace (Chrisman et al., 2013). Interpretation of these findings is, however, complicated by ambiguity about the dimensions of the stewardship construct, the relationship among these dimensions, and the impact of the empirical research context upon the findings.

First, received theory stresses that stewardship influences a variety of organizational behaviors, extending from farsighted financial investments (e.g., Le Breton-Miller, Miller, \& Lester, 2011) to pro-social employment practices such as generous employee compensation, decentralized decision-making, and high levels of investment in employee training (Arregle et al., 2007; Corbetta \& Salvato, 2004; Miller \& Le Breton-Miller, 2006). Most empirical studies, however, capture only a subset of these dimensions (Neubaum, Thomas, Dibrell, \& Craig, 2017). For example, Le Breton-Miller and colleagues (2011) associate stewardship with farsighted financial behavior, and measure it using secondary data from Fortune 1000 firms and an index comprised of financial ratios. In contrast, other researchers (e.g., Davis, Allen, \& Hayes, 2010; Eddleston \& Kellermanns, 2007) stress the collectivist, pro-social dimensions of the construct and use survey methods to measure a variety of organizational attributes. 
Second, theory is ambiguous about the relationship between these and other potential dimensions of stewardship. For example, Davis et al. (2010, 1997) and others (e.g., Lee \& O’Neill, 2003) suggest that farsighted financial management of the firm, or financial stewardship, supports the adoption of collaborative and inclusive managerial practices that benefit non-owner stakeholders, or organizational stewardship. Hernandez (2012) argues, however, that financial stewardship is but one among many behaviors that are antecedent to the emergence and institutionalization of organizational stewardship. Moreover, the relatively widespread notion that stewardship behaviors emerge over a period of time (Madison et al., 2016) also implies that financial stewardship may sometimes be antecedent to, and hence not concomitant with, organizational stewardship.

Finally, Davis et al. (1997) and Madison et al. (2016) argue that governance practices that are commonplace in public firms, such as the use of incentive compensation and emphasis on short-run financial performance, can deter stewardship. Miller et al. (2008) and others (Corbetta \& Salvato, 2004; Eddleston \& Kellermanns, 2007; Frey, 1993, 1997) therefore argue that stewardship behaviors are most likely to emerge when ownership is private and owners are free to implement policies that maximize their welfare. To date, however, research about stewardship in private firms has relied on cross-sectional data—a research strategy that may be incommensurate with institutionalization or other time-dependent dimensions of the construct. Curiously, and to the best of our knowledge, no prior study of private firms has used longitudinal data and robust secondary measures of both financial and organizational practices in tests of stewardship theory.

In this paper, we seek to overcome these limitations in the research literature by proposing that tests of stewardship in family firms should not only explore financial stewardship, 
which we define as farsighted financial management of the firm, but also organizational stewardship, which we define as stewardship behavior towards non-owner stakeholders, like employees. In doing so, we extend stewardship and agency theories from their traditional focus on governance and performance, to employment practices in private firms, and test our propositions using 19 years of detailed financial and employment data from 14,961 privatelyheld Belgian firms. Our data suggest that family firms are better financial stewards than nonfamily firms, as indicated by higher investment, lower dividend payout, and higher risk tolerance, but are worse organizational stewards: Compensation is lower, investment in employee training is less, voluntary turnover is higher, and labor productivity is lower than in nonfamily firms. In addition, and contrary to Le Breton-Miller et al. (2011), we find that financial stewardship does not change while organizational stewardship worsens as family firms age, and that high levels of family involvement or identification with the firm do little to offset these outcomes.

This study makes several contributions to the research literature. First, we conceptually and empirically extend stewardship theory by developing and testing specific propositions about the financial and organizational dimensions of the construct. Second, we extend agency and stewardship theory to employment practices, and in so doing, contextualize these theories in a manner that enhances their utility in research about both private firms and family firms. Third, our paper adds to the growing literature about how family control shapes firm conduct in general and employment practice in particular (e.g., Chrisman, Devaraj, \& Patel, 2017). Answering this question is important because family firms employ 60 percent of the global workforce. Our study suggests that family ownership has a detrimental effect on employment practices, which is particularly worrisome when labor market failures limit job mobility. Lastly, earlier research 
about the influence of family on firm governance has proven largely noncumulative due to conceptual, empirical, and methodological heterogeneity across studies (Neubaum et al., 2017; Zahra, Hayton, Neubaum, Dibrell, \& Craig, 2008). By probing a large sample of detailed financial and employment data from a large number of private firms from a single country over a significant period of time, we overcome limitations of earlier studies and add to the growing literature about whether, when, and under what conditions family firms might engage in stewardship behavior (Chrisman et al., 2017; Gómez-Mejía et al., 2003, 2001; Le Breton-Miller et al., 2011; Sraer \& Thesmar, 2007).

\section{THEORETICAL FOUNDATIONS}

Over the past decade, two perspectives about the influence of family on firm management have emerged. The first, derived from agency theory, is based on the premise that actors are selfinterested and that the risk preferences of owners and employees differ, with employees being more risk averse than owners (Eisenhardt, 1989; Jensen \& Meckling, 1976). The divergence of interests between owners and their employees, along with costly information, makes it difficult for owners to hire motivated employees and makes their supervision necessary. While ownermanagement reduces the costs of monitoring and incentivizing employees, family involvement provides added incentive to use the information available to the family as insiders to opportunistically exploit nonfamily employees and disenfranchise minority owners (Schulze et al., 2001; Young, Peng, Ahlstrom, Bruton, \& Jiang, 2008). Examples of owner opportunism include basing decisions on personal preference as opposed to professional (business) judgment (Gedajlovic \& Carney, 2010), using firm resources to advance the family's personal welfare (Schulze et al., 2001), securing employment and benefits for family members (Volpin, 2002), and the adoption of governance structures that assure the family's continued control of the 
enterprise (Morck, Wolfenzon, \& Yeung, 2005). The result is a series of agency hazards that threaten firm performance in general and employee welfare in particular.

The second theoretical perspective describes family managers as stewards who act in trustworthy, collectivistic, and pro-organizational ways and are intrinsically motivated to care about the welfare of the enterprise (Davis et al., 1997). Proponents assert that there is a strong alignment between the behavioral premises advanced in stewardship theory and the humanistic values and behaviors espoused in family firms. This is because family managers identify strongly with their firm, are motivated to assure its long-run survival, and tend to be deeply embedded in its socioeconomic context (Corbetta \& Salvato, 2004; Gómez-Mejía, Cruz, Berrone, \& De Castro, 2011; Le Breton-Miller et al., 2011; Zellweger, Nason, Nordqvist, \& Brush, 2013). Davis et al. (2010) and Corbetta and Salvato (2004) suggest these attributes nurture a stewardship culture that motivates family members to care about their employees, and stimulates high levels of commitment, trust and loyalty among employees. In sum, the stewardship perspective depicts family firms as fertile grounds for beneficial work practices (Eddleston, Kellermanns, \& Zellweger, 2012).

While received theory states that stewards are concerned with the financial wellbeing of the firm because most "stakeholder groups have interests that are well-served by increasing organizational wealth" (Davis et al., 1997: 25), it is ambiguous about the mechanisms that engender stewardship as well as the relationship between the organizational and financial dimensions of the construct. For example, Davis et al. (1997), Eddleston, Kellermanns, and Sarathy (2008), and Zahra et al. (2008) suggest that organizational stewardship originates in family identification with the enterprise and that a sense of kinship obligation motivates family members to care about their employees, as well as the firm's well-being and continuity (Arregle 
et al., 2007). The resulting relationship-centered behaviors foster a culture of commitment to the business around which the family can build an enduring relationship with its employees, nurture a sense of responsibility among employees to one another and to the enterprise as a whole. Hernandez $(2008,2012)$ and others (Segal \& Lehrer, 2012) identify other antecedents, and suggest that shared leadership, ongoing investment in employee development and training, promotion of a long-term perspective, and affective commitment to and psychological ownership of the firm also motivate the emergence and institutionalization of stewardship.

Moreover, Hernandez (2012) observes that existing theory stresses that stewardship is characterized by a long-term orientation toward the enterprise (e.g., Davis et al., 1997; 2010). Measures of this dimension, however, often fail to distinguish between the cognitive dimension of the underlying construct (i.e., the time orientation of decision-makers), actual firm conduct (i.e., the time horizon of an investment or employment decision), and the extent to which these are associated with the steward's underlying motivation to take actions that benefit the welfare of other stakeholders (Breton-Miller \& Miller, 2006; James, 1999; Zellweger, 2007). In sum, ambiguity about the theoretical mechanisms that engender stewardship, the dimensionality of the construct and the relationship between these dimensions, as well as the role of time therein leads to conflation among concepts and makes interpretation of the empirical record difficult.

\section{Stewardship in private and family firms}

While stewardship theory was originally developed and tested using data from public, professionally-managed firms (e.g., Davis et al., 2010, 1997; Donaldson \& Davis, 1991), Davis et al. $(2010,1997)$ and others (Donaldson \& Preston, 1995; Hernandez, 2008) observe that stewardship behavior can be deterred by the presence of governance practices that seek to constrain employee behaviors, such as monetary incentives and external monitoring. Norms of 
professional conduct, as well as outside and institutional investor expectations, may also motivate public firms to implement governance practices aimed at deterring agency costs (Hartzell \& Starks, 2003). Donaldson and Davis (1991) and others (Corbetta \& Salvato, 2004; Eddleston \& Kellermanns, 2007; Le Breton-Miller \& Miller, 2009; Miller \& Le Breton-Miller, 2006) therefore suggest that the emergence of stewardship behaviors, and the adoption of managerial and compensation practices that support them, are most likely to occur when ownership is private. The focus on private firms is also theoretically appropriate because concentrated ownership and owner oversight should lead to the adoption of managerial practices and firm strategies that most closely reflect the welfare interests of the owners.

However, research to date about the impact of family on firm conduct has been noncumulative due to conceptual and methodological heterogeneity across studies. For example, the notion that agency prevails among family firms has primarily been examined using secondary longitudinal data from large family-controlled publicly-traded firms (Anderson \& Reeb, 2003, 2004; Gómez-Mejía et al., 2003; Villalonga \& Amit, 2006). The problem is that the size of these firms, alongside significant oversight by outside (e.g., nonfamily and institutional) owners, limits the generalizability of related findings about family influence on firm governance. In contrast, the notion that stewardship prevails in family firms was primarily tested using cross-sectional surveys of small to medium-sized private firms (Craig \& Dibrell, 2006; Eddleston et al., 2012; Zahra, 2003). This stream of stewardship research tends to focus on organizational and strategic dimensions of family firm conduct and relies on subjective measures like commitment (Vallejo, 2009), corporate entrepreneurship (Eddleston et al., 2012), organizational climate (Neubaum et al., 2017), strategic flexibility (Zahra et al., 2008), innovativeness (Craig \& Dibrell, 2006), and entrepreneurial behavior of employees (Sieger, Zellweger, \& Aquino, 2013). As a result, 
Neubaum et al. (2017) argue that past stewardship research has been overly reliant on measures that capture only a subset of potential variables that stewardship might influence. They call for research that tests these theories using robust measures whose scope encompasses the organization as a whole (e.g., Crook, Todd, Combs, Woehr, \& Ketchen, 2011; Jiang, Lepak, Hu, $\&$ Baer, 2012). This call for future research is especially pertinent because stewardship theory suggests its benefits should strongly manifest in the collective behavior of the workforce (Neubaum et al., 2017).

In the sections that follow, we seek to extend agency and stewardship perspectives by testing theory about financial and organizational stewardship in private family and nonfamily firms. Financial practices (as represented by investment in capital equipment and R\&D, dividend payout, and risk tolerance) and employment practices (as represented by compensation, training, and dismissals, along with the product of these employment practices, such as voluntary turnover and labor productivity), serve as our proxies for financial and organizational stewardship. Our premise is that if governance in private family firms indeed reflects the particular welfare interests of its owners, then family involvement may cause its financial and employment practices to differ from those that characterize nonfamily firms. Accordingly, we take the nonfamily firm as our baseline and anticipate the impact of family is to contour financial and employment practices in ways that are commensurate with the prevailing theory (stewardship or agency) and allows the family to capture related benefits from its control of the enterprise.

\section{Financial Stewardship in Family Firms}

To date, researchers have drawn on both agency and stewardship theory to explore the impact of private ownership and family on the financial conduct of the firm. In the main, agency theory suggests that controlling families have incentive to use firm resources to enhance their 
welfare (Carrasco-Hernandez \& Sánchez-Marín, 2007; Chrisman, Memili, \& Misra, 2014; Le Breton-Miller et al., 2011). For example, La Porta, Lopez-de-Silanes, and Shleifer (1999) and Lins, Volpin, and Wagner (2013) identify a variety of practices that allow family members to extract dividends and perquisites from firms they control in amounts that exceed their cash flow rights, and document that such practices are pervasive. Agency perspectives also lead us to anticipate that family firms will be more risk averse than nonfamily firms. Risk aversion can be attributed to the effects of concentrated wealth (Morck, Shleifer, \& Vishny, 1988), as well as limited liquidity and reduced access to capital (Miller et al., 2008; Schulze, Lubatkin, \& Dino, 2003; Villalonga \& Amit, 2006, 2009). Agency conflict among family shareholders (Villalonga \& Amit, 2006; Young et al., 2008; Zellweger \& Kammerlander, 2015) can also impair strategic decision-making, slowing the firm's ability to respond to market change or reach decisions about fixed asset investment (Lubatkin, Durand, \& Ling, 2007; Schulze et al., 2003). Finally, decisionmakers in family firms may feel bounded by the legacy of the founder and/or tradition (Gedajlovic, Lubatkin, \& Schulze, 2004), and so may be less willing to diversify into faster growing, albeit riskier, market segments (Gómez-Mejía, Patel, \& Zellweger, 2015). In sum, agency theory leads us to propose that family control should negatively impact financial stewardship of the firm, as indicated by lower investment, higher dividend payout and lower risk tolerance than nonfamily firms.

In contrast, stewardship theory suggests that family ownership will positively impact financial stewardship. Le Breton-Miller et al. (2011) and others (Eddleston \& Kellermanns, 2007; Anderson \& Reeb, 2003) suggest that stewardship behaviors are associated with investments in new products, research and development, and capital investments that help sustain the long run competitive position of the firm. They also suggest family firms are inclined to 
tolerate risks in order to support long-term, uncertain investments in infrastructure and renewal. Because such investments require flexible funding (Le Breton-Miller et al., 2011), family firms are inclined to rely on internally generated financial resources (over which they have greater discretion) and eschew high dividend payouts. These considerations lead us to conclude that family firms are likely to exhibit higher financial stewardship than nonfamily firms. Together with earlier arguments, we conclude that agency and stewardship theories suggest:

Hla: Financial stewardship is lower in family firms than in nonfamily firms H1b: Financial stewardship is higher in family firms than in nonfamily firms

\section{Organizational Stewardship in Family Firms}

Interestingly, evidence for financial stewardship may not, by itself, be sufficient to conclude that organizational stewardship is present and/or likely to arise. For example, financial stewardship could also be motivated by familial altruism, along with desires for financial and employment security for the family (Madison et al., 2016; Pearson \& Marler, 2010) or dynastic motivations to preserve transgenerational control of the firm (Zellweger, Kellermanns, Chrisman, \& Chua, 2012). Schulze et al. (2001; 2003) note that familial altruism gives family members powerful incentives to care more about the welfare of family members than nonfamily stakeholders. This incentive motivates family firms to undertake long-term investments, which secures family member employment and preserves family control of the enterprise. These investments, however, may only indirectly benefit nonfamily employees; e.g., they may reduce employment risk. However, the resources required to support these investments may come at the expense of nonfamily stakeholders, including nonfamily employees. Relatedly, finding that family firms are willing to take on more risks when both financial and socioemotional wealth is at stake (Gómez-Mejía, Haynes, Núñez-Nickel, Jacobson, \& Moyano-Fuentes, 2007), suggests 
that the risk posture of family firms — an important aspect of financial stewardship—may be motivated by the owners' concerns for their own welfare, and not stewardship motivations for nonfamily stakeholders. We conclude that evidence of financial stewardship may not, by itself, be a positive indicator of organizational stewardship. It follows that a focus on organizational dimensions of stewardship is needed to better assess the presence / absence of stewardship behavior in family firms, as well as the more general merits of the theory.

\section{Compensation}

To date, researchers have drawn on both agency and stewardship theory to explore the influence of family control on managerial compensation. For example, Werner, Tosi, and Gómez-Mejía (2005) adopt an agency frame and suggest managerial compensation is lower in family firms because family managers do not require additional compensation to assure the alignment of managerial and ownership interests. Combs, Penney, Crook, and Short (2010) note that family involvement, as well as the family's long-term association with the enterprise, reduces monitoring costs and information asymmetries, which alleviates upward pressure on managerial compensation. Interestingly, Combs et al. (2010) also find that family managers earn significantly less than nonfamily managers when multiple family members are involved in management.

Stewardship perspectives also point in the direction of lower managerial compensation in family firms than in nonfamily firms: Managers who act as stewards are willing to forgo higher compensation because the manager's personal interests are naturally aligned with those of the firm. Out of identification, pride, loyalty, fealty and other higher order needs (Davis et al., 1997; Miller \& Le Breton-Miller, 2006), managers seek to make the family firm successful for a wide set of stakeholders. In such cases, managers are expected to exercise forbearance with 
respect to their own compensation since this improves the collective wellbeing of the firm and facilitates the funding of other organizational initiatives (Davis et al., 1997; Wasserman, 2006). Stewardship proponents argue these effects should be particularly pronounced for family managers, but should also prevail if a nonfamily steward serves at the helm of the family firm. For instance, Miller and Sardais (2011) coin the term 'angel agents' to describe professional CEOs who use their superior information and status to the benefit of the firm and its various stakeholders.

However, agency and stewardship theories generate diverging predictions about the level of overall compensation of the workforce in family as opposed to nonfamily firms. As noted earlier, agency proponents contend that family members have incentive to use firm resources to enhance their own welfare (Chrisman et al., 2014; Le Breton-Miller et al., 2011) which puts downward pressure on overall compensation (Carrasco-Hernandez \& Sánchez-Marín, 2007). Moreover, Werner et al. (2005: 378) argue the impact on overall pay levels is direct because the "impact of ownership structure on pay-performance relations cascades to lower rungs of the organizational ladder.” In line with this argument, Carrasco-Hernandez and Sánchez-Marín (2007) suggest that levels of overall compensation in family firms should be lower than in nonfamily firms because family managers earn less (Pittino et al., 2016), and because it is standard practice for organizations to maintain pay differentials between levels as ratios (Jaskiewicz, Block, Miller, \& Combs, 2017; Simon, 1957).

Stewardship theory suggests a contrasting outcome. Since stewardship is intrinsically motivated by an attitude of service toward others, it should manifest in practices that support employee welfare. For example, Arregle et al. (2007) observe that family stewardship supports the development of a corporate culture marked by loyalty, informality, and reciprocity, and 
promotes a greater sense of identification with both the firm and family (Vallejo, 2009; Zahra et al., 2008). When individuals identify with their organization, they more readily engage in cooperative, altruistic, and unrewarded citizenship behaviors and are motivated by service to others, not merely self-interest (Jaskiewicz et al., 2017; Zellweger et al., 2013). It follows that family owners will be willing to deter benefits (Davis et al., 1997) and invest in the firm and its workforce "to make the firm healthy and durable and to enhance value for all stakeholders" (Le Breton-Miller et al., 2011: 704). In sum, while agency arguments predict lower compensation, stewardship arguments lead us to expect higher compensation in family firms as opposed to nonfamily firms. Specifically:

H2a: Compensation is lower in family firms than in nonfamily firms.

H2b: Compensation is higher in family firms than in nonfamily firms.

\section{Training}

Agency and stewardship theories can also be extended to generate competing predictions about family firm investment in employee training. Agency perspectives suggest that selfinterested family members are less likely to make investments if benefits are not directly appropriable by the firm. For instance, offering employees educational benefits such as subsidizing the cost of acquiring an MBA, and hence investing in general (i.e., non-firm specific) knowledge, is problematic from an agency perspective because it increases the potential value of the employee to other employers.

In contrast, generously investing in human capital is viewed as characteristic of a stewardship culture (Miller et al., 2008). Such investment empowers the workers, serves as a strong signal of trust from the side of management, and provides employees with the means to take action on their own and to deal with uncertainty (Beehr, Drexler, \& Faulkner, 1997). The 
family firms' willingness to invest in its long-run competitive capabilities, along with commitment to employee welfare and a need for employee retention should motivate these firms to generously invest in the development of their human capital. Off-site training, which tends to be less firm-specific, can be used by the firm as a signal of its long-run and selfless commitment to employee welfare. It can also be viewed as an investment in enhanced employee retention, motivation, and empowerment (Davis et al., 1997). Consequently, we expect that agentic family firms will invest less, and steward-like family firms will invest more in off-site training than nonfamily firms.

H3a: Investment in off-site training is lower for family firms than nonfamily firms.

H3b: Investment in off-site training is higher for family firms than nonfamily firms.

\section{Dismissals}

Agency and stewardship theories also make competing predictions about dismissals. A byproduct of perceived inequities in the supervision and compensation of nonfamily employees, along with discriminatory promotion practices, is adverse selection (Chrisman et al., 2013). As a result, family firms often have difficulty attracting high quality workers (Bassanini et al., 2013; Verbeke \& Kano, 2012), and may be forced to hire from a suboptimal talent pool (Schulze et al., 2001). Indeed, abundant anecdotal evidence documents that family firms are especially challenged to hire and retain skilled employees (Barnett \& Kellermanns, 2006; Gersick, 1997; Lansberg, 1983). This increases the likelihood of making poor hires and, as a consequence, may increase the rate of dismissals. Dismissals might also be viewed as necessary to sustain or improve performance (Nixon, Hitt, Lee, \& Jeong, 2004) and may be more likely to occur when agentic behaviour is prevalent. 
In contrast, organizational stewardship should perhaps be most evident in the continuity of employment relationships and the presence of a loyal and committed workforce (Allouche \& Amann, 1998; Goffee \& Scase, 1985). Family firms are said to value benevolent relationships with nonfamily employees and other stakeholders (Cennamo, Berrone, Cruz, \& Gómez-Mejía, 2012). Consistent with these sentiments, several labor market studies find that family firms offer nonfamily employees greater job security, have lower rates of dismissals, and prefer to rely on attrition rather than dismissals when faced with a need to reduce their workforce (e.g., Bassanini et al., 2013; Block, 2010; Sraer \& Thesmar, 2007). Summing up, agency leads us to expect greater rates of dismissals, while stewardship suggests that family firms should exhibit lower rates of dismissals when compared to nonfamily firms.

H4a: Dismissals are greater in family firms than in nonfamily firms.

H4b: Dismissals are lower in family firms than in nonfamily firms.

\section{Voluntary Turnover}

Agency perspectives lead us to expect that self-interested conduct by family members will be associated with higher levels of voluntary turnover. For example, a desire to advance family welfare may lead the firm to engage in nepotism when hiring and promoting employees, thereby limiting advancement opportunities for nonfamily employees (Volpin, 2002). Altruism can also make it difficult for family firms to monitor and discipline family members (Schulze et al., 2001), leading to perceived inequities in the supervision and compensation of family and nonfamily employees (Lubatkin et al., 2007). Relatedly, reduced voice and violations of procedural justice are associated with higher levels of voluntary turnover (Shaw, Gupta, \& Delery, 2005). Family favoritism also compromises standards of professional practice and may make it difficult for family firms to retain talented employees (Chrisman et al., 2017; Pérez- 
González, 2006). Nyberg (2010) and others (Trevor, Gerhart, \& Boudreau, 1997; Vroom, 1964) argue employees are more likely to leave when there is an unclear line of sight between performance and rewards and perceptions of unfairness. Also, a family's aversion to losses that might threaten their ability to sustain family control (Gómez-Mejía et al., 2007) may reduce investments, such as in research, new product development, and other initiatives (Chrisman \& Patel, 2012; Duran, Kammerlander, Van Essen, \& Zellweger, 2016), which makes the workplace less attractive to highly skilled employees. Together, these agency predictions suggest that the workplace environment in family firms should be characterized by higher levels of voluntary turnover among nonfamily employees.

In contrast, stewardship cultures should lead family firms to exercise care in their treatment of employees (Miller et al., 2008). Miller et al. (2008) suggest that with stewardship, people are welcomed and the workplace takes on an "atmosphere of a cohesive shop" (Miller et al., 2008: 56). A high commitment atmosphere (Davis et al., 1997) leads employees to engage with the firm for the long-run (Vardaman et al., 2016), motivates employees to undertake initiatives (Miller et al., 2008), and resolves problems associated with adverse selection. Pittino et al. (2016) also argue that generous family firm employment practices enhance employees' intention to stay. Summing up, while agency arguments point at higher rates of voluntary turnover in family firms, stewardship suggests that family firms should exhibit lower rates of voluntary employee turnover when compared to nonfamily firms.

H5a: Voluntary employee turnover is greater in family firms than in nonfamily firms.

H5b: Voluntary employee turnover is lower in family firms than in nonfamily firms.

\section{Labor productivity}


Labor productivity, defined as the ratio of firm outputs to labor inputs (Samuelson \& Nordhaus, 1989), is a critical indicator of workforce performance (Datta, Guthrie, \& Wright, 2005; Kim \& Ployhart, 2014). In light of our agency predictions, we expect family firms to exhibit lower labor productivity than nonfamily firms. This prediction is rooted in established agency arguments suggesting that labor productivity is at least partially a function of both moral hazards, such as misaligned interests between owners and managers, and adverse selection, such as from hiring from a suboptimal talent pool (Akerlof, 1970; Eisenhardt, 1989; Jensen \& Meckling, 1976). In conjunction with recent arguments from the family business (Chrisman et al., 2017; Cucculelli, Mannarino, Pupo, \& Ricotta, 2014) and finance (Barth et al., 2005; Burkart, Panunzi, \& Shleifer, 2003) literatures, we suggest that these problems are particularly severe in family firms. Moral hazards are rampant given the diverging interests of family owners and their nonfamily employees (Chua, Chrisman, \& Bergiel, 2009; Schulze et al., 2001). Indeed, Dyer (2006: 264) states that "nonfamily employees are [often] treated as 'second-class citizens' and ... such an adversarial relationship between an owning family and nonfamily employees often results in low employee morale and low productivity." Adverse selection is a consequence of family firms' preferential treatment of family members in hiring and promotion decisions, which undermines the quality of the workforce (Bassanini et al., 2013; Verbeke \& Kano, 2012). This should adversely impact productivity since the limited ability of the workforce also translates into reduced effort of the workforce (Chua et al., 2009).

In contrast, stewardship perspectives suggest the interests of both principals and agents are naturally aligned because both behave in ways that are consistent with organizational objectives (Argyris, 1964; Davis et al., 1997). This solves underlying moral hazard problems and should lead to higher labor productivity (FitzRoy \& Kraft, 1987; Florkowski, 1987; Kruse, 
Freeman, \& Blasi, 2010; Steinherr, 1977). Indeed, Sraer and Thesmar (2007), probing a sample of French firms, find that family firms exhibit a higher labor productivity because these firms provide their workers with long-term implicit insurance contracts, and hence a higher job security (Bassanini et al., 2013). Sraer and Thesmar (2007) suggest that family control endows the firm with enough credibility to enforce implicit contracts and makes it possible for family firms to generate more output with fewer resources. Employee rewards in steward-like environments include opportunities for personal growth, achievement, and self-actualization (Davis et al., 1997), factors that are associated with high levels of productivity (Barth et al., 2005). In sum, our theories suggest:

H6a: Labor productivity is lower in family firms than in nonfamily firms.

H6b: Labor productivity is higher in family firms than in nonfamily firms.

\section{SAMPLE AND METHODS}

We test our hypotheses using data of Belgian family firms from 1996 to 2014. We obtained our data from Bureau van Dijk (BvD), one of Europe's leading electronic publishers of business information. Belgium represents a unique "laboratory" to study employment practices since all Belgian non-financial firms that employ staff_-irrespective of their size and age_-have a legal obligation to annually file detailed social balance accounts, along with their financial accounts, in a predefined format with the Belgian National Bank. On a yearly basis, firms report over fifty employee-related variables. To be part of our sample, we required firms to have 20 employees (or more accurately, full time equivalents) during at least one year of the 1996-2014 period. We applied this cut-off because the Belgian National Bank allows smaller firms to submit social balance sheets in an abbreviated format with more limited information. After 
winsorizing our data at the $1 \%$ level to reduce the potential influence of outliers, our final dataset consists of 102,094 firm years of data from 14,961 private firms.

Starting from this dataset, we follow Chang and Shim (2015) and others (Boivie, Graffin, Oliver, \& Withers, 2016; Chrisman et al., 2017) and use a propensity-based matched pair design as the principal method in tests of our hypotheses. Propensity score matching lowers the influence of unobserved heterogeneity, lowers chances of Type 1 error, and provides more conservative estimates than regressions (Dehejia \& Wahba, 2002). The method generates a vector score using a specified set of covariates for each observation, and then matches it with the closest scoring observation in the respective subset. The method then estimates the differences between family and nonfamily firm observations for each of our dependent variables. We should note that we match firm years rather than firms. As such, we take into account that firms that form a good match in one year, may not necessarily form a good match over the full sample period (Dehejia \& Wahba, 2002). Boivie et al. (2016) and Chrisman et al. (2017) suggest that annual matching minimizes the risk of dissimilar matching due to extreme values of any of the covariates, thereby allowing for a relatively bias-free and conservative test of our hypotheses. We employ propensity score matching using the psmatch 2 package in Stata 13.1, using matching without replacement in all analyses.

Starting from our original dataset of 14,961 firms and 102,094 firm years of data, we test hypotheses concerning financial stewardship, compensation, dismissals, voluntary turnover, and labor productivity $(\mathrm{H} 1, \mathrm{H} 2, \mathrm{H} 4, \mathrm{H} 5$, and $\mathrm{H} 6)$ with a sample that contains 39,600 firm years of data and covers the period 1996 to 2014. Following the matching process, half of these observations were from family firms $(19,800)$ and half were from nonfamily firms $(19,800)$. These datasets are smaller than the original because the matching process is conservative, and 
drops dissimilar cases. Because it was not until 2008 that firms were first required to publish information regarding training initiatives and education levels, we use a restricted sample period for the hypothesis concerning off-site training (H3). The sample used to test H3 contains 14,382 firm years of data between 2008 and 2014. Again, half of these observations are from family firms $(7,191)$ and half are from nonfamily firms $(7,191)$.

We employ a conservative test strategy. First, we test for the influence of family on financial (H1) and organizational stewardship (H2 through H6) by matching family and nonfamily firms using a baseline set of covariates (Firm age, Firm size, Capital intensity, Region, Industry, and Year in tests for Financial stewardship; and Firm age, Firm size, Capital intensity, Region, Industry, Year, Male, Blue Collar, Permanent Contracts, and Firm Growth in tests for Organizational stewardship). In a second set of models, we control for the potential influence of financial stewardship on organizational stewardship by adding financial stewardship to the baseline set of matching covariates in our tests of $\mathrm{H} 2$ through $\mathrm{H} 4$. Finally, in our tests for Voluntary Turnover (H5) and Labor Productivity (H6) we include all prior dependent variables (financial stewardship, compensation, off-site training, and dismissals) as matching covariates along with our baseline set of matching covariates.

\section{Dependent Variables}

We use six dependent variables in this study: Financial stewardship, Compensation, OffSite Training, Dismissals, Voluntary turnover, and Labor productivity. First, we adapt Le Breton-Miller et al. (2011: 711) to the private firm context and limitations of our data and measure Financial stewardship as the sum of three ratios: The annual investment in capital equipment and R\&D (expressed as a percentage of fixed assets), the inverse of the dividend payout ratio (1 - total dividends as a percentage of earning) and risk tolerance (coefficient of 
variation of a firm's earnings before interest, taxes, depreciations, and amortizations). The latter is commonly employed as a measure of venture risk in private firms (Bromiley, 1991;

Fiegenbaum \& Thomas, 1988; Gómez-Mejía et al., 2007; Miller, Wiseman, \& Gómez-Mejía, 2002). All variables were standardized and summed to create a composite index of financial stewardship.

We measured Compensation as total labor related expenses ${ }^{1}$ in a given firm-year divided by the total number of hours worked in the same firm-year (Price \& Mueller, 1981).

Compensation was measured in euros and corrected for inflation because Belgian compensation is tied to overall inflation. ${ }^{2}$ Off-Site Training initiatives are defined as courses or internships, characterized by a high degree of organization by a trainer or training institution, and must take place at a site separated from the workplace. Often participants acquire a certificate for taking the training. Importantly, Off-Site Training excludes initiatives that are directly related to the task and the workplace of the employee such as, coaching, training through rotation, and in-house workshops. ${ }^{3}$ The social balance sheets report the net training costs payable by the employer, i.e., the salaries and social contributions for employees in training, as well as education, registration fees, costs for teaching material, transportation costs, less subsidies from local and federal governments and/or European Union financial support. Off-Site Training is therefore measured as the total net costs in thousand euros a firm spends on training during a given year divided by the total number of employees (measured as full-time equivalents or FTE). Finally, we follow the human resource management literature (e.g., Shaw, Delery, Jenkins, \& Gupta, 1998) and

\footnotetext{
${ }^{1}$ Total labor related expenses include salaries and other costs in so far they are part of an employment contract, e.g. direct social benefits, social insurance contributions, and bonuses granted as part of an employment contract.

2 The GDP deflator for 1996 was employed in all models.

${ }^{3}$ We consulted the "Explanatory note regarding training activities included in the social balance" as published by the Belgian National Bank for a detailed description of the training activities that must be reported as part of the annual accounts (www.nbb.be/en/central-balance-sheet-office).
} 
measure Dismissals as the number of employees (FTE) who were dismissed by the firm during a given firm-year divided by the number of employees (FTE) at the start of that firm-year.

We measured Voluntary Turnover as the number of employees (FTE) who voluntarily left the firm during a given firm-year divided by the number of employees (FTE) at the start of that firm-year. Following recent strategic management research (Bertrand \& Capron, 2015) and in accordance with labor economics literature (e.g., Bassanini et al., 2013; Sraer \& Thesmar, 2007) we measured Labor Productivity as value added for the year divided by the average number of employees (FTE) during that year. Value added is the firm's total revenue minus its costs of non-labor inputs. We log transformed this variable to correct for its skewed distribution. We prefer this measure to the more popular alternative, which measures labor productivity as the ratio of firm sales to number of employees (Datta et al., 2005; Guthrie, 2001; Huselid, 1995). This is because the latter does not control for potential increases in non-labor costs that may accompany revenue generation (Datta et al., 2005).

\section{Independent Variable}

Family Firm is a dummy variable (1/0) that identifies family firms. Consistent with multiple other studies we use a composite measure to classify firms as family controlled (Gómez-Mejía et al., 2015; Patel \& Chrisman, 2014) and define family firm if: (i) a family holds more than 50 percent of the shares of the firm, and (ii) at least two board members share the same last name. We benefit from a research setting in which all firms are legally required to publish detailed information about the composition of their board of directors in the Belgian Law Gazette. Moreover, this data is externally validated by notaries. In cases where ownership data was missing, we follow Wilson, Wright, and Scholes (2013) and Westhead and Cowling (1998) 
and identify family firms as those in which family board members comprised 20 percent or more of the board. In sum, our approach allows for a conservative classification of family firms.

\section{Matching Covariates / Control Variables}

As noted above, in tests of Financial Stewardship (H1) we follow prior literature and match family and nonfamily firm observations on Firm Age, Firm Size, Capital Intensity, Region, Industry classification, and Year (Anderson \& Reeb, 2003; Le Breton-Miller et al., 2011). We measure Firm Age as the number of years since the founding of the firm, and Firm Size as the total number of employees as measured by fulltime equivalents. We log transformed both variables to correct for their skewed distribution. We control for Capital Intensity, measured as the ratio of the firm's fixed assets to the number of its employees, because capital intensity may affect the investment and risk tolerance aspect of our financial stewardship measure (Amihud \& Lev, 1981; Miller \& Bromiley, 1990). We log transformed this variable to correct for its skewed distribution. To control for differences between the two main geographical regions in Belgium, Flanders, and Wallonia, we added Flanders, which is a dummy variable (1/0) indicating a firm's location. ${ }^{4}$ Lastly, we also matched observations based on firm Industry Classification (2-digit industry code) and Year of observation.

In tests for Compensation (H2), Off-site Training (H3), Dismissals (H4), Voluntary turnover (H5) and Labor Productivity (H6), we retain Firm Size, Firm Age, Capital Intensity, Flanders, Industry Classification, and Year, and add Male, Blue Collar, Permanent Contracts, and Firm Growth as additional matching covariates. We retain Firm Age because older firms generally have more experienced employees with higher tenure (Brown \& Medoff, 2003). We retain Capital Intensity as a matching covariate to control for possible relationships with

\footnotetext{
${ }^{4}$ Flanders is more economically prosperous than Wallonia. The regions also differ culturally (Dutch v. French).
} 
employment practices, voluntary turnover, and labor productivity (Bertrand \& Capron, 2015;

Datta et al., 2005), and, in line with previous studies (e.g. Guthrie, 2001; Jackson \& Schuler, 1995), we also retain Firm Size, Flanders, industry classification, and year of observation. We add Male and Blue Collar to control for potential gender and workforce composition influences (Joshi, Jooyeon Son, \& Hyuntak Roh, 2015; Osterman, 2006; Trevor \& Nyberg, 2008). We measure both as the percentage of the workforce measured in full time equivalents at year end. We also control for variance in job security by matching firms on Permanent Contracts and measure it as a percentage of the workforce at year-end (Boyce, Ryan, Imus, \& Morgeson, 2007). Following Huselid (1995), we also match observations based on Firm Growth, measured as the employment size change (FTE) during a given year divided by the number of employees (FTE) at the beginning of that year.

To make sure that potential differences in Compensation, Off-site Training and Dismissals are not influenced by the strategic combination or bundling of HR practices (e.g., Becker \& Huselid, 1998; Guthrie, 2001; Macduffie, 1995), we add Dismissals as a matching covariate when Compensation is the dependent variable, and add Compensation when Dismissals is the dependent variable. Similarly, we add Compensation and Dismissals as matching covariates when Off-Site Training is the dependent variable. ${ }^{5}$ We did not include Off-site Training as a matching covariate in the main models because it was not until 2008 that firms were first required to publish information regarding training initiatives. We included Off-site Training as a matching covariate in robustness tests and found results to be consistent.

\footnotetext{
${ }^{5}$ We do not include Off-site Training as matching covariate when Compensation or Dismissals are the dependent variables, because it was not until 2008 that data for Off-site Training was available. In our robustness test section for the time period 2008-2014 we however relax this assumption (Table 5) and add Off-site Training in the tests for Compensation and Dismissals. The results are consistent. As part of the robustness tests, we also excluded these control variables and also here found results to be consistent.
} 


\section{RESULTS}

Table 1 presents means, standard deviations, and correlations for the full sample. Visual inspection identifies no anomalies. The average firm is 26 years old, has 88 employees, and 31 million euro in sales. Table 2 displays mean comparison tests for family and nonfamily firms for the entire sample. The workforce of family firms is more blue collar (61\% vs $40 \%)$ and male (79\% vs 69\%). Family firms are also older (27 years vs 25 years) and smaller (70 vs 93 FTE) than nonfamily firms. Table 2 also reports that family firms exhibit higher Financial Stewardship, pay average Compensation that is about 17 percent lower than in nonfamily firms (4.7 inflation adjusted euros per hour), invest 42 percent less in Off-site training, have 0.3 percent fewer Dismissals, and Labor Productivity is 21 percent less than in nonfamily firms. No differences in Voluntary Turnover were observed in Table 2.

\section{---- Insert Tables 1 and 2 here ----}

Table 3, Panel A presents the results from our hypotheses tests using propensity score matching and using the set of matching covariates as specified above. Financial stewardship is higher $(0.062 ; \mathrm{p}<0.001)$ in family firms. Compensation is 1.9 euro per hour $(-1.896 ; \mathrm{p}<0.001)^{6}$ or 8 percent lower in family firms. Family firms spend less on Off-Site Training than nonfamily firms $(-0.022 ; \mathrm{p}<0.001)$. Dismissals do not differ. Voluntary Turnover is 1.4 percent higher in family firms $(0.014 ; \mathrm{p}<0.001)$. Labor productivity is 10.8 percent lower in family firms than in nonfamily firms $(-7.601 ; \mathrm{p}<0.001)$. As anticipated, propensity score matching generates estimates that are smaller, and hence more conservative, than those found in the population at large reported in Table 2.

\footnotetext{
${ }^{6}$ In 1996 euro. In 2016 euro this amounts to 2.45 EUR / hour. Inflation data retrieved from www.inflation.eu.
} 
Table 3, Panel B presents the results including Financial Stewardship as an additional matching covariate in the models where Compensation, Off-Site Training, Dismissals, Voluntary Turnover, and Labor productivity are the dependent variables. As such, these analyses examine the influence of family on the employment variables over and above the effects of Financial Stewardship. As shown, Compensation remains lower (-1.800; p < 0.001), Off-Site Training lower (-0.019; $\mathrm{p}<0.001)$, Voluntary turnover higher $(0.014 ; \mathrm{p}<0.001)$, and Labor Productivity (-7.038; $\mathrm{p}<0.001)$ lower in family firms. Dismissals do not differ.

Table 3, Panel C presents the results including Financial Stewardship, Compensation, Off-Site Training, and Dismissals as additional matching covariates in the models with Voluntary Turnover and Labor Productivity as the dependent variables. As such, these analyses examine the influence of family on Voluntary Turnover and Labor Productivity over and above the effects of Financial Stewardship, Compensation, Off-Site Training and Dismissals. As shown, Voluntary Turnover remains higher $(0.009 ; \mathrm{p}<0.001)$ and Labor Productivity lower $(-2.259 ; \mathrm{p}<$ 0.001) in family firms.

Taken together, the data thus supports the hypotheses that, compared to nonfamily firms, family firms display higher Financial Stewardship (H1b) but lower organizational stewardship, as represented by lower Compensation (H2a), lower Off-Site Training (H3a), higher Voluntary Turnover (H5a), and lower Labor Productivity (H6a).

\section{--- Insert Table 3 here ---}

We also assessed the validity and rigor of the propensity score matching by comparing the sample means of all variables included in the matching process between the family and nonfamily firm groups and performing individual T-tests (Chang \& Shim, 2015). The results confirm that our matching groups are well balanced (see Appendix A). Propensity score 
histograms further confirmed that the distribution of propensity scores was uniform and well balanced irrespective of the dependent variable of interest (available upon request).

\section{Post-Hoc Analyses}

While the support for higher financial stewardship and absence of support for organizational stewardship is surprising, a potential explanation is that the nature of the relationship between family ownership and financial stewardship and/or organizational stewardship changes as firms' age. If so, the observed main effects (reported above) may mask the true underlying relationship between family control, financial stewardship, and organizational stewardship. There is some support for this view in the literature. For example, Le Breton-Miller et al. (2011) and others (Verbeke \& Kano, 2012; Wasserman, 2006) propose that family firms are steward-like when run by their founders, but turn agentic when their descendants become involved in firm management and oversight. Increased agentic behavior arises over time as the founder becomes less engaged in the firm and is hence less able to resist familial pressure to divert firm resources to family consumption, and as family demands on firm resources rise with the increased size of the extended family. Steward-like motives may also decline over time because family members tend to become less emotionally attached to the firm, share less of an identity with it, and become less loyal to the firm and its various stakeholders (Gómez-Mejía et al., 2007). Le Breton-Miller et al. (2011) therefore anticipate that scions will come to see the firm as a utilitarian asset from which they can extract private benefits. Data from family-controlled Fortune 1000 corporations (Le Breton-Miller et al., 2011), and a sample of 528 venture-capital backed private technology firms (Wasserman, 2006), lend general support to these conjectures. 
We also explore potential relationships between firm age and other moderators that have been described in the research literature. For example, a number of authors (e.g., Barnett \& Kellermanns, 2006; Miller et al., 2008; Zahra, 2003) suggest that the family influence on firm conduct is shaped by the level of family involvement in firm oversight. Accordingly, we interact firm age with Family Board Involvement, which is measured as the percentage of directors belonging to the family (Zahra, 2003: 03). Others argue that stewardship behavior can also be induced when family members share a strong sense of identity with the firm, and suggest that the family name, firm name, and reputation become progressively linked as they age (Berrone, Cruz, Gómez-Mejía, \& Larraza-Kintana, 2010; Zellweger et al., 2013). Accordingly, we follow Deephouse and Jaskiewicz (2013) and Dyer and Whetten (2006) and interact firm age with a dummy variable, Family-firm Identity Overlap (1/0), which indicates whether the family's name is included in the firm's name.

Table 4 presents the results from these post-hoc tests. Table 4 indicates that financial stewardship does not change as firms mature but confirms that the deleterious influence of family on organizational stewardship rises with both firm age and heightened family involvement. Compensation is negatively related with Firm Age x Family Firm (-0.032; p < 0.01), with Firm Age x Family Board Involvement (-0.053; p < 0.001), and with Firm Age $x$ Family-firm Identity Overlap $(-0.038 ; \mathrm{p}<0.001)$. Table 4 also indicates that Off-Site Training declines as family firms age $(-0.001 ; \mathrm{p}<0.001)$. In contrast, Firm Age x Family-firm Identity Overlap is positively associated with levels of Voluntary Turnover $(0.001 ; \mathrm{p}<0.001)$.

\section{---- Insert Table 4 here ----}

To aid interpretation, plots of all significant interactions in Table 4 are presented in Figure 1. The figures are illuminating since they suggest the net effect of family influence is, in 
the main, to reduce the rate of change as firms' age. Compensation in family firms, for example, does not rise proportionately with the rise of compensation in nonfamily firms as firms age, and the plots of other relationships for family firms are flat or trend slightly negative. The absence of an interaction with nonfamily firm employment practice (the slopes do not cross) also indicates our data do not support Le Breton-Miller et al.'s (2011) conjecture that employment practice changes over time from steward-like to agentic. Rather, compensation, training, and turnover in private family firms are below the levels observed for private nonfamily firms in all plots, for all observed values of our dependent variables, across all ranges of firm age.

\section{---- Insert Figure 1 here ----}

\section{Robustness Tests}

We conducted several additional analyses to ensure the robustness of the results. First, we added Educational Level, measured as the number of employees having completed tertiary education (university or college) divided by the total number of employees, as a covariate in the models for Compensation, Off-Site Training, Dismissals, Voluntary turnover, and Labor Productivity. This matching covariate was not included in the main analyses because it was not until 2008 that firms were required to report this variable. Results, shown in Table 5, were highly consistent with the exception of Dismissals, which was lower in family firms when controlling for Financial Stewardship $(-0.003 ; \mathrm{p}<0.01)$. Again, we assessed the validity and rigor of the propensity score matching in these samples and found that our matching groups are well balanced.

Second, we explore the prospect that our results on overall compensation are influenced by levels of family member compensation by comparing overall compensation levels in larger and smaller firms. If results are sensitive to levels of family compensation, overall compensation 
should differ between small firms (in which the effect of generous family compensation might be observed) and large firms (where family effects will be diluted by firm scale). Accordingly, we follow Bassanini et al. (2013) and ran all regressions on establishments with more or less than 50, 40, and 30 FTE respectively. No material differences are observed, which suggests that earnings of family members do not account for the observed differences in family and nonfamily compensation (results available on request).

Third, we used random effects regression to test for the proposed differences among family and nonfamily firms, and also lagged our control and independent variables by one year. Results, presented in Table 6, Panels A and B, indicate that when compared to nonfamily firms, family firms show higher Financial stewardship (0.074; p < 0.001), lower Compensation (2.809; $\mathrm{p}<0.001)$, lower Off-Site Training (-0.032; $\mathrm{p}<0.001)$, higher Voluntary turnover ( 0.007 ; $\mathrm{p}<0.05)$, and lower Labor Productivity $(-0.163 ; \mathrm{p}<0.001)$. Dismissals did not differ. These results are consistent with the findings from the propensity score matching analysis presented in Table 3. We note that the coefficients for family firms in all regressions models are larger than the average treatment effects obtained from propensity score matching, suggesting that propensity score matching indeed provides for a more conservative test of the proposed relationships. We also performed random effects regression for the restricted time period for which Education was available, and used Education as a control variable. This further analysis provided results consistent with the ones reported in Table 6.

Fourth, we tested the sensitivity of our firm classification variable by using 15 percent and 30 percent board representation as our cutoff when coding our family firm dummy variable. No material differences in results were observed. Lastly, we probed our models using a variety of interaction terms to rule out the prospect that our results were influenced by an indirect 
relationship between financial and organizational stewardship. No significant two-way

relationship between financial and organizational stewardship, or three-way relationship between those variables and other independent variables, were identified.

We conclude that our primary analyses, the results of our post-hoc tests of moderation and those of our robustness tests, provide overall support for the hypothesis that family firms in comparison to nonfamily firms are characterized by higher Financial Stewardship (H1b) but lower Organizational Stewardship, as indicated by lower Compensation (H2a), lower Off-Site Training (H3a), higher Voluntary Turnover (H5a) and lower Labor Productivity (H6a).

\section{--- Insert Table 5 and 6 here ----}

\section{DISCUSSION}

Are family firms good stewards who provide generously for their employees? Our results, using data from more than 14,000 firms over 19 years, are revealing. Propensity score matching results suggest that family firms pay 7 percent less to their employees, invest 14 percent less in off-site employee training, and have about 1 percent more voluntary employee turnover than nonfamily firms. Labor productivity of family firms is 3.3 percent lower than in nonfamily firms, which is consistent with earlier research that also found that family firms are less productive (e.g. Barth et al., 2005; Chrisman et al., 2017; Wall, 1998). ${ }^{7}$ And, contrary to earlier studies, dismissal rates in family and nonfamily firms did not materially differ. However, the data also indicate that family firms are more reliable financial stewards who are willing to tolerate risk, undertake farsighted investments by drawing on internally generated sources of capital and eschewing dividends. The overall pattern of results, along with post hoc analyses and a variety of robustness

\footnotetext{
7 These are the most conservative results from our various tests. They are, however, in line with earlier studies. Barth et al. (2005) measured total factor productivity and report family firms were $10 \%$ to $14 \%$ less productive. Wall (1998) and Chrisman et al. (2017) measure labor productivity as sales per employee and report that family firms are $18 \%$ to $21 \%$ less productive.
} 
tests, confirm that family firms are good financial stewards but are surprisingly poor organizational stewards.

The results of this study, along with our theorizing, have variety of implications for theory, practice, and policy making. First, we conceptually and empirically extend stewardship theory by developing and testing specific propositions about the financial and organizational dimensions of the construct. This contribution is important because, to date, researchers have used measures of these dimensions interchangeably, and by doing so, imply that either can serve as a reliable proxy for the over-arching construct (e.g. Le Breton-Miller et al., 2011; Neubaum et al., 2017). We show that the measures are independent and demonstrate that, at least in the case of private family firms, organizations may score high in one dimension of stewardship and low in another. These findings are also important because they raise the prospect that financial stewardship may not, by itself, reflect the pursuit of goals that are consistent with stewardship (Davis et al., 1997). Rather, and as outlined above, financial stewardship could also be motivated by familial altruism (Schulze et al., 2001), the pursuit of financial and employment security for the family (Gómez-Mejía et al., 2003) or dynastic motivations to preserve transgenerational control of the firm (Zellweger, Kellermanns, Chrisman, \& Chua, 2012). The negative impact of family on compensation and other employment practices, the absence of offsetting indirect effects (such as changes in employment practice over time like improved job security or investment in training), along with persistent investment in their financial welfare, is thus especially striking. Our theory and findings therefore caution against reliance on single measures of stewardship, and suggests research that relied solely on financial measures of the construct may merit re-evaluation. 
Second, we extend agency and stewardship theory to employment practices and in so doing contextualize the two theories in ways that enhance their utility in research beyond the family business context. For instance, our study extends agency and stewardship theory work from its prior focus on managerial compensation (Combs et al., 2010; Gómez-Mejía et al., 2003, 2001), to a wider set of employment practices that apply to the workforce as a whole. In doing so, our study untangles the theoretical mechanisms that explain the respective presence or absence of financial and organizational stewardship and helps resolve some of the ambiguity in the existing literature about the differential impact of agency and stewardship on organizations (Hernandez, 2008, 2012; Segal \& Lehrer, 2012).

Third, our paper adds to the growing literature about how family control shapes employment practices (e.g., Chrisman et al., 2017; Combs et al., 2010; Gómez-Mejía et al., 2003, 2001; Le Breton-Miller et al., 2011; Sraer \& Thesmar, 2007). Answering this question is important because family firms employ 60 percent of the global workforce. Evidence that family firms are not generous employers (that is, are worse organizational stewards) has important implications for economies in which labor market failures limit job mobility (Dreher \& Cox, 2000). Our findings also differ starkly with earlier studies that report more positive accounts of employment practices in family firms (e.g., Bammens, Notelaers, \& Van Gils, 2015; Cennamo et al., 2012; Miller \& Le Breton-Miller, 2006; Pittino et al., 2016; van Essen, van Oosterhout, \& Heugens, 2013). Rather, our evidence indicates that family firms are initially agentic toward the workforce (that is, they are worse organizational stewards than nonfamily firms), and become even more agentic over time. We wish to be clear: We are not challenging studies that find family firms are good financial stewards. Nor are we questioning studies that claim employees in family firms are sometimes treated as family (Barnett \& Kellermanns, 2006), and/or are well 
compensated by their employers. However, the results of our study indicate that this may be the exception rather than the norm. Also, our work more closely aligns with the human resource literature, in which compensation is but one dimension of employment practice (e.g., Combs, Liu, Hall, \& Ketchen, 2006; Jiang et al., 2012; Wright \& McMahan, 1992), and differs from earlier studies of family firms that study selected employment practices (e.g., Sraer \& Thesmar, 2007; Bassanini et al., 2013).

Fourth, we believe our study raises important questions about the utility of stewardship theory because we: (1) measure two dimensions of stewardship, (2) study family firms, organizations that have been repeatedly associated with stewardship behaviors (Corbetta \& Salvato, 2004; Le Breton-Miller et al., 2011), (3) study private firms—an environment in which organizational practices should most closely align with the welfare interest of owners, (4) use robust measures of each dimension over a substantial period of time - a period that should be sufficient to capture the time dependent dimensions of the model, (5) draw from a sample collected by a national bank mandated with the compilation of a social balance sheet with detailed information on how employees are treated by employers, and (6) focus on variables (financial and employment practices) that are unambiguously associated with both stewardship and agency theories, and for which these theories make competing predictions. In sum, our study is situated in an organizational and empirical context in which we would expect the effects of the prevailing theoretical model of man (i.e., agency theory's self-interested man, or stewardship's pro-social model of man) to manifest and be readily observed.

Our findings also remind us that context matters: While data from both our study and that of Le Breton-Miller et al. (2011) confirm that family firms are (or become) agentic, the party that is harmed by family control in our study of private firms is employees. In Le Breton-Millet et al. 
(2011) and others (e.g., Lemmon \& Lins, 2003) the parties that are financially harmed are the minority shareholders in public firms. Evidence that family firms are agentic in both contexts therefore lends weight to agency perspectives. The absence of unambiguous evidence for stewardship theory in the context of private family firms leads us to join with Bosse and Phillips (2016) and Wiseman et al. (2012) who suggest that perhaps more progress about corporate governance can be achieved through efforts to "repair rather than replace agency theory" (Bosse \& Phillips, 2016: 280).

\section{Implications for practice}

Evidence that employment practices in Belgian family firms systematically differ from nonfamily firms has important implications for practice. First, our findings suggest Belgian employees might want to exercise caution when seeking employment from family firms. Family firm employees typically earn less, receive less training that might enhance the value of their human capital, and, apparently, voluntarily leave employment at higher rates than those employed by nonfamily firms. Second, our data lend only limited support to the assertion that family firms exhibit lower dismissal rates than nonfamily firms (Block, 2010; Sraer \& Thesmar, 2007; van Essen, Strike, Carney, \& Sapp, 2015), and in cases where they differ, the effect sizes are small. Notions that family firm employees trade lower wages against a higher job security (Bassanini et al., 2013) may therefore be misplaced. These factors should loom even larger for employees in economies characterized by regulations that limit job mobility. Lastly, these results may serve to alert family business owners to the deleterious consequences that family control may have on the commitment and the quality of workforce, productivity, and ultimately the prosperity of the firm (Crook et al., 2011; Jiang et al., 2012). 
Our study also has important policy implications because family firms represent, by some estimates, over 90 percent of all firms worldwide (Gedajlovic, Carney, Chrisman, \& Kellermanns, 2012) and employ roughly 60 percent of the world's workforce (Family Firm Institute, 2016). Evidence that family control does not promote employee welfare is disconcerting. Policy makers interested in enhancing job quality and employee welfare may therefore find these findings to be particularly interesting (Bassanini, Booth, Brunello, De Paola, \& Leuven, 2005; Davoine, Erhel, \& Guergoat-Lariviere, 2008; Wagner, 1997).

\section{Limitations}

Despite the merits of our study, its generalizability may be limited. First, we looked at a restricted albeit important set of employment practices. However, and as Neubaum et al. (2017) note, stewardship claims might be best viewed as manifest in the organization's climate. Data about employees' job satisfaction, commitment, citizenship behavior, teamwork, and performance appraisal, might also be required to more completely test the theories' claims (Carlson, Upton, \& Seaman, 2006; Kotey \& Folker, 2007). Our study is situated in Belgium, and naturally reflects the country-specific employment regulations, such as legal protection of employment, collective labor action, employee involvement in firm decision making, and unionization. While this prevented us from exploring institutional variations (van Essen et al., 2013), this shortcoming should be weighed against the opportunity to explore labor practices in a large longitudinal sample for which the same labor market regulations apply. The fact that we test for intra-national variance (Flanders vs Wallonia) does, however, provide some assurance that some institutional influences have been taken into account.

While endogeneity is a concern in every study, we have little reason to expect that our data suffers from omitted variable bias. Propensity score matching lowers the influence of 
unobserved heterogeneity, lowers chances of Type 1 error, and provides more conservative estimates (Dehejia \& Wahba, 2002). Also, our results hold after controlling for important alternate explanations such as workforce composition and so forth.. Additionally, our data is longitudinal, which improves the ability to draw causal inferences. In conjunction with the quality of our data and our careful robustness tests, we have no reason to assume that our data suffers from important endogeneity biases.

\section{Future Research}

While stewardship theory remains popular (Madison et al., 2016), the results of this study suggest this emphasis may be misplaced. Our results support recent calls for fresh theorizing on firm governance, strategic human resource management, and the establishment of cooperation in organizations (Bosse \& Phillips, 2016; Sundaramurthy \& Lewis, 2003), especially in closelyheld firms (Schulze \& Zellweger, 2016). When viewed against the backdrop of the strategic human resource literature, our findings suggest that the world's most common form of economic organization, the private family firm, faces challenges relative to the nonfamily firm in its ability to resolve important human capital and employee motivation problems (Crook et al., 2011; Jiang et al., 2012). Surprisingly, our data suggest that despite their long-term orientation, family firms may be challenged to motivate employees to be productive and to develop the types of high quality human capital that is associated with sustained operating performance of the firm (Coff, 1997, 2010; Crook et al., 2011; Huselid, 1995). These concerns are all the more pressing because employee welfare directly impacts what employees are willing to do, how hard they are willing to work, as well as their ability to adapt to changing economic conditions (Chadwick, 2016; Coff, 1999).

\section{Conclusion}


To date, a growing stream of research has documented that family interests strongly influence the conduct and performance of family enterprise. As it turns out, this study suggests that family firms are good financial stewards, but poor organizational stewards - they pay less, invest less in employee training, have greater voluntary employee turnover, and contrary to a central claim of stewardship theory, are less productive than nonfamily firms. With the present study we hope to build a stepping stone for more work in a field of research that holds wide theoretical and practical promise. 


\section{REFERENCES}

Akerlof, G. A. 1970. The market for "lemons": Quality uncertainty and the market mechanism. Quarterly Journal of Economics, 84(3): 488-500.

Allouche, J., \& Amann, B. 1998. La confiance: une explication des performances des entreprises familiales. Economies et Sociétés, 32: 129-154.

Amihud, Y., \& Lev, B. 1981. Risk reduction as a managerial motive for conglomerate mergers. The Bell Journal of Economics, 12(2): 605-617.

Anderson, R. C., \& Reeb, D. M. 2003. Founding-family ownership and firm performance: evidence from the S\&P 500. The Journal of Finance, 58(3): 1301-1328.

Anderson, R. C., \& Reeb, D. M. 2004. Board composition: Balancing family influence in S\&P 500 firms. Administrative Science Quarterly, 49(2): 209-237.

Argyris, C. 1964. Integrating the organization and the individual. NY: Wiley.

Arregle, J.-L., Hitt, M. A., Sirmon, D. G., \& Very, P. 2007. The development of organizational social capital: Attributes of family firms. Journal of Management Studies, 44(1): 73-95.

Bammens, Y., Notelaers, G., \& Van Gils, A. 2015. Implications of family business employment for employees' innovative work involvement. Family Business Review, 28(2): 123-144.

Barnett, T., \& Kellermanns, F. W. 2006. Are we family and are we treated as family? Nonfamily employees' perceptions of justice in the family firm. Entrepreneurship Theory and Practice, 30(6): 837-854.

Barth, E., Gulbrandsen, T., \& Schønea, P. 2005. Family ownership and productivity: The role of owner-management. Journal of Corporate Finance, 11(1-2): 107-127.

Bassanini, A., Booth, A. L., Brunello, G., De Paola, M., \& Leuven, E. 2005. Workplace training in Europe. https://papers.ssrn.com/sol3/papers.cfm?abstract_id=756405.

Bassanini, A., Breda, T., Caroli, E., \& Rebérioux, A. 2013. Working in family firms: Paid less but more secure? Evidence from French matched employer-employee data. Industrial \& Labor Relations Review, 66(2): 433-466.

Becker, B. E., \& Huselid, M. A. 1998. High performance work systems and firm performance: A synthesis of research and managerial implications. Research in Personnel and Human Resource Management, (16): 53-101.

Beehr, T. A., Drexler, J. A., \& Faulkner, S. 1997. Working in small family businesses: Empirical comparisons to non-family businesses. Journal of Organizational Behavior, 18(3): 297312.

Berrone, P., Cruz, C., Gómez-Mejía, L. R., \& Larraza-Kintana, M. 2010. Socioemotional wealth and corporate responses to institutional pressures: Do family-controlled firms pollute less? Administrative Science Quarterly, 55(1): 82-113.

Bertrand, M., \& Schoar, A. 2006. The role of family in family firms. The Journal of Economic Perspectives, 20(2): 73-96.

Bertrand, O., \& Capron, L. 2015. Productivity enhancement at home via cross-border acquisitions: The roles of learning and contemporaneous domestic investments: CrossBorder Acquisitions and Domestic Productivity. Strategic Management Journal, 36(5): 640-658.

Block, J. 2010. Family management, family ownership, and downsizing: Evidence from S\&P 500 firms. Family Business Review, 23(2): 109-130.

Boivie, S., Graffin, S. D., Oliver, A. G., \& Withers, M. C. 2016. Come aboard! Exploring the effects of directorships in the executive labor market. Academy of Management Journal, 59(5): 1681-1706. 
Bosse, D. A., \& Phillips, R. A. 2016. Agency theory and bounded self-interest. Academy of Management Review, 41(2): 276-297.

Boyce, A. S., Ryan, A. M., Imus, A. L., \& Morgeson, F. P. 2007. "Temporary worker, permanent loser?" A model of the stigmatization of temporary workers. Journal of Management, 33(1): 5-29.

Breton-Miller, L., \& Miller, D. 2006. Why do some family businesses out-compete? Governance, long-term orientations, and sustainable capability. Entrepreneurship Theory and Practice, 30(6): 731-746.

Bromiley, P. 1991. Testing a causal model of corporate risk taking and performance. Academy of Management Journal, 34(1): 37-59.

Brown, C., \& Medoff, J. L. 2003. Firm age and wages. Journal of Labor Economics, 21(3): 677-697.

Burkart, M., Panunzi, F., \& Shleifer, A. 2003. Family firms. The Journal of Finance, 58(5): 2167-2202.

Carlson, D. S., Upton, N., \& Seaman, S. 2006. The impact of human resource practices and compensation design on performance: An analysis of family-owned SMEs. Journal of Small Business Management, 44(4): 531-543.

Carrasco-Hernandez, A., \& Sánchez-Marín, G. 2007. The determinants of employee compensation in family firms: Empirical evidence. Family Business Review, 20(3): 215228.

Cennamo, C., Berrone, P., Cruz, C., \& Gómez-Mejía, L. R. 2012. Socioemotional wealth and proactive stakeholder engagement: Why family-controlled firms care more about their stakeholders. Entrepreneurship Theory and Practice, 36(6): 1153-1173.

Chadwick, C. 2016. Towards a more comprehensive model of firms' human capital rents. Academy of Management Review, Forthcoming.

Chang, S.-J., \& Shim, J. 2015. When does transitioning from family to professional management improve firm performance? Transition from family to professional management. Strategic Management Journal, 36(9): 1297-1316.

Chrisman, J. J., Devaraj, S., \& Patel, P. C. 2017. The impact of incentive compensation on labor productivity in family and nonfamily firms. Family Business Review, 0894486517690052.

Chrisman, J. J., Memili, E., \& Misra, K. 2014. Nonfamily managers, family firms, and the winner's curse: The influence of noneconomic goals and bounded rationality. Entrepreneurship Theory and Practice, 38(5): 1103-1127.

Chrisman, J. J., \& Patel, P. C. 2012. Variations in R\&D investments of family and nonfamily firms: Behavioral agency and myopic loss aversion perspectives. Academy of Management Journal, 55(4): 976-997.

Chrisman, J. J., Sharma, P., Steier, L. P., \& Chua, J. H. 2013. The influence of family goals, governance, and resources on firm outcomes. Entrepreneurship Theory and Practice, 37(6): 1249-1261.

Chua, J. H., Chrisman, J. J., \& Bergiel, E. B. 2009. An agency theoretic analysis of the professionalized family firm. Entrepreneurship Theory and Practice, 33(2): 355-372.

Coff, R. W. 1997. Human assets and management dilemmas: Coping with hazards on the road to resource-based theory. Academy of Management Review, 22(2): 374-402.

Coff, R. W. 1999. When Competitive Advantage Doesn't Lead to Performance: The ResourceBased View and Stakeholder Bargaining Power. Organization Science, 10(2): 119-133. 
Coff, R. W. 2010. The coevolution of rent appropriation and capability development. Strategic Management Journal, 31(7): 711-733.

Combs, J. G., Penney, C. R., Crook, T. R., \& Short, J. C. 2010. The impact of family representation on CEO compensation. Entrepreneurship Theory and Practice, 34(6): 1125-1144.

Combs, J., Liu, Y., Hall, A., \& Ketchen, D. 2006. How much do high-performance work practices matter? A meta-analysis of their effects on organizational performance. Personnel Psychology, 59(3): 501-528.

Corbetta, G., \& Salvato, C. 2004. Self-serving or self-actualizing? Models of man and agency costs in different types of family firms: A commentary on "Comparing the agency costs of family and non-family firms: Conceptual issues and exploratory evidence."

Entrepreneurship Theory and Practice, 28(4): 355-362.

Craig, J., \& Dibrell, C. 2006. The natural environment, innovation, and firm performance: A comparative study. Family Business Review, 19(4): 275.

Crook, T. R., Todd, S. Y., Combs, J. G., Woehr, D. J., \& Ketchen, D. J. 2011. Does human capital matter? A meta-analysis of the relationship between human capital and firm performance. Journal of Applied Psychology, 96(3): 443-456.

Cucculelli, M., Mannarino, L., Pupo, V., \& Ricotta, F. 2014. Owner-management, firm age, and productivity in Italian family firms. Journal of Small Business Management, 52(2): 325-343.

Datta, D. K., Guthrie, J. P., \& Wright, P. M. 2005. Human resource management and labor productivity: Does industry matter? Academy of Management Journal, 48(1): 135-145.

Davis, J. H., Allen, M. R., \& Hayes, H. D. 2010. Is blood thicker than water? A study of stewardship perceptions in family business. Entrepreneurship Theory and Practice, 34(6): 1093-1116.

Davis, J. H., Schoorman, F. D., \& Donaldson, L. 1997. Toward a stewardship theory of management. Academy of Management Review, 22(1): 20.

Davoine, L., Erhel, C., \& Guergoat-Lariviere, M. 2008. Monitoring quality in work: European Employment Strategy indicators and beyond. International Labour Review, 147(2-3): 163-198.

Deephouse, D. L., \& Jaskiewicz, P. 2013. Do family firms have better reputations than nonfamily firms? An integration of socioemotional wealth and social identity theories: corporate reputation in family firms. Journal of Management Studies, 50(3): 337-360.

Dehejia, R. H., \& Wahba, S. 2002. Propensity score-matching methods for nonexperimental causal studies. Review of Economics and Statistics, 84(1): 151-161.

Donaldson, L., \& Davis, J. H. 1991. Stewardship theory or agency theory: CEO governance and shareholder returns. Australian Journal of Management, 16(1): 49-64.

Donaldson, T., \& Preston, L. E. 1995. The stakeholder theory of the corporation: Concepts, evidence, and implications. Academy of Management Review, 20(1): 65.

Dreher, G. F., \& Cox, T. H. 2000. Labor market mobility and cash compensation: The moderating effects of race and gender. Academy of Management Journal, 43(5): 890900.

Duran, P., Kammerlander, N., Van Essen, M., \& Zellweger, T. 2016. Doing more with less: Innovation input and output in family firms. Academy of Management Journal, 59(4): 1224-1264. 
Dyer, W. G. 2006. Examining the "family effect" on firm performance. Family Business Review, 19(4): 253-273.

Eddleston, K. A., \& Kellermanns, F. W. 2007. Destructive and productive family relationships: A stewardship theory perspective. Journal of Business Venturing, 22(4): 545-565.

Eddleston, K. A., Kellermanns, F. W., \& Sarathy, R. 2008. Resource configuration in family firms: Linking resources, strategic planning and technological opportunities to performance. Journal of Management Studies, 45(1): 26-50.

Eddleston, K. A., Kellermanns, F. W., \& Zellweger, T. M. 2012. Exploring the entrepreneurial behavior of family firms: Does the stewardship perspective explain differences? Entrepreneurship Theory and Practice, 36(2): 347-367.

Eisenhardt, K. M. 1989. Agency theory: An assessment and review. Academy of Management Review, 14(1): 57-74.

Family Firm Institute. 2016. Global Data Points. http://www.ffi.org/?page=GlobalDataPoints.

Fiegenbaum, A., \& Thomas, H. 1988. Attitudes toward risk and the risk-return paradox: Prospect theory explanations. Academy of Management Journal, 31(1): 85-106.

FitzRoy, F. R., \& Kraft, K. 1987. Cooperation, productivity, and profit sharing. The Quarterly Journal of Economics, 102(1): 23-35.

Florkowski, G. W. 1987. The organizational impact of profit sharing. Academy of Management Review, 12(4): 622-636.

Frey, B. S. 1993. Does monitoring increase work effort? The rivalry with trust and loyalty. Economic Inquiry, 31(4): 663-670.

Frey, B. S. 1997. On the relationship between intrinsic and extrinsic work motivation1. International Journal of Industrial Organization, 15(4): 427-439.

Gedajlovic, E., \& Carney, M. 2010. Markets, hierarchies, and families: Toward a transaction cost theory of the family firm. Entrepreneurship Theory and Practice, 34(6): 1145-1172.

Gedajlovic, E., Carney, M., Chrisman, J. J., \& Kellermanns, F. W. 2012. The adolescence of family firm research taking stock and planning for the future. Journal of Management, 38(4): 1010-1037.

Gedajlovic, E., Lubatkin, M. H., \& Schulze, W. S. 2004. Crossing the threshold from founder management to professional management: A governance perspective. Journal of Management Studies, 41(5): 899-912.

Gersick, K. E. 1997. Generation to Generation: Life Cycles of the Family Business. Harvard Business Press.

Goffee, R., \& Scase, R. 1985. Proprietorial control in family firms: Some functions of "quasiorganic" management systems. Journal of Management Studies, 22(1): 53-68.

Gómez-Mejía, L. R., Cruz, C., Berrone, P., \& De Castro, J. 2011. The bind that ties: Socioemotional wealth preservation in family firms. Academy of Management Annals, 5(1): 653-707.

Gómez-Mejía, L. R., Haynes, K. T., Núñez-Nickel, M., Jacobson, K. J. L., \& Moyano-Fuentes, J. 2007. Socioemotional wealth and business risks in family-controlled firms: Evidence from Spanish olive oil mills. Administrative Science Quarterly, 52(1): 106-137.

Gómez-Mejía, L. R., Larraza-Kintana, M., \& Makri, M. 2003. The determinants of executive compensation in family-controlled public corporations. Academy of Management Journal, 46(2): 226-237.

Gómez-Mejía, L. R., Nuñez-Nickel, M., \& Gutierrez, I. 2001. The role of family ties in agency contracts. Academy of Management Journal, 44(1): 81-95. 
Gómez-Mejía, L. R., Patel, P. C., \& Zellweger, T. M. 2015. In the horns of the dilemma socioemotional wealth, financial wealth, and acquisitions in family firms. Journal of Management. https://doi.org/0149206315614375.

Graves, C., \& Shan, Y. G. 2014. An empirical analysis of the effect of internationalization on the performance of unlisted family and nonfamily firms in Australia. Family Business Review, 27(2): 142-160.

Guthrie, J. P. 2001. High-involvement work practices, turnover and productivity: Evidence from New Zealand. Academy of Management Journal, 44(1): 180-190.

Hartzell, J. C., \& Starks, L. T. 2003. Institutional Investors and Executive Compensation. The Journal of Finance, 58(6): 2351-2374.

Hernandez, M. 2008. Promoting stewardship behavior in organizations: A leadership model. Journal of Business Ethics, 80(1): 121-128.

Hernandez, M. 2012. Toward an understanding of the psychology of stewardship. Academy of Management Review, 37(2): 172-193.

Huselid, M. A. 1995. The impact of human resource management practices on turnover, productivity, and corporate financial performance. Academy of Management Journal, 38(3): 635-672.

Jackson, S. E., \& Schuler, R. S. 1995. Understanding human resource management in the context of organizations and their environments. Annual Review of Psychology, 46(1): 237.

James, H. S. 1999. Owner as manager, extended horizons and the family firm. International Journal of the Economics of Business, 6(1): 41-55.

Jaskiewicz, P., Block, J. H., Miller, D., \& Combs, J. G. 2017. Founder versus family owners' impact on pay dispersion among non-CEO top managers: Implications for firm performance. Journal of Management, 43(5): 1524-1552.

Jensen, M. C., \& Meckling, W. H. 1976. Theory of the firm: Managerial behavior, agency costs and ownership structure. Journal of Financial Economics, 3(4): 305-360.

Jiang, K., Lepak, D. P., Hu, J., \& Baer, J. C. 2012. How does human resource management influence organizational outcomes? A meta-analytic investigation of mediating mechanisms. Academy of Management Journal, 55(6): 1264-1294.

Joshi, A., Jooyeon Son, \& Hyuntak Roh. 2015. When can women close the gap? A meta-analytic test of sex differences in performance and rewards. Academy of Management Journal, 58(5): 1516-1545.

Kachaner, N., Stalk, G., \& Bloch, A. 2012. What you can learn from family business. Harvard Business Review, 90(11): 102-106.

Kim, Y., \& Ployhart, R. E. 2014. The effects of staffing and training on firm productivity and profit growth before, during, and after the Great Recession. Journal of Applied Psychology, 99(3): 361-389.

Kotey, B., \& Folker, C. 2007. Employee training in SMEs: Effect of size and firm type - family and nonfamily. Journal of Small Business Management, 45(2): 214-238.

Kruse, D. L., Freeman, R. B., \& Blasi, J. R. 2010. Shared capitalism at work: Employee ownership, profit and gain sharing, and broad-based stock options. University of Chicago Press.

La Porta, R., Lopez-De-Silanes, F., \& Shleifer, A. 1999. Corporate ownership around the world. The Journal of Finance, 54(2): 471-517.

Lansberg, I. S. 1983. Managing human resources in family firms: The problem of institutional overlap. Organizational Dynamics, 12(1): 39-46. 
Le Breton-Miller, I., \& Miller, D. 2009. Agency vs. stewardship in public family firms: A social embeddedness reconciliation. Entrepreneurship Theory and Practice, 33(6): 1169-1191.

Le Breton-Miller, I., Miller, D., \& Lester, R. H. 2011. Stewardship or agency? A social embeddedness reconciliation of conduct and performance in public family businesses. Organization Science, 22(3): 704-721.

Lee, P. M., \& O’Neill, H. M. 2003. Ownership structures and R\&D investments of U.S. and Japanese firms: Agency and stewardship perspectives. Academy of Management Journal, 46(2): 212-225.

Lemmon, M. L., \& Lins, K. V. 2003. Ownership structure, corporate governance, and firm value: Evidence from the East Asian financial crisis. The Journal of Finance, 58(4): 14451468.

Lins, K. V., Volpin, P., \& Wagner, H. F. 2013. Does family control matter? International evidence from the 2008-2009 financial crisis. The Review of Financial Studies, 26(10): 2583-2619.

Lubatkin, M. H., Durand, R., \& Ling, Y. 2007. The missing lens in family firm governance theory: A self-other typology of parental altruism. Journal of Business Research, 60(10): 1022-1029.

Macduffie, J. P. 1995. Human resource bundles and manufacturing performance: Organizational logic and flexible production systems in the world auto industry. ILR Review, 48(2): 197-221.

Madison, K., Holt, D. T., Kellermanns, F. W., \& Ranft, A. L. 2016. Viewing family firm behavior and governance through the lens of agency and stewardship theories. Family Business Review, 29(1): 65-93.

Miller, D., \& Le Breton-Miller, I. 2006. Family governance and firm performance: Agency, stewardship, and capabilities. Family Business Review, 19(1): 73-87.

Miller, D., Le Breton-Miller, I., \& Scholnick, B. 2008. Stewardship vs. stagnation: An empirical comparison of small family and non-family businesses. Journal of Management Studies, 45(1): 51-78.

Miller, D., Minichilli, A., \& Corbetta, G. 2013. Is family leadership always beneficial? Strategic Management Journal, 34(5): 553-571.

Miller, D., \& Sardais, C. 2011. Angel agents: Agency theory reconsidered. Academy of Management Perspectives, 25(2): 6-13.

Miller, J. S., Wiseman, R. M., \& Gómez-Mejía, L. R. 2002. The fit between ceo compensation design and firm risk. Academy of Management Journal, 45(4): 745-756.

Miller, K. D., \& Bromiley, P. 1990. Strategic risk and corporate performance: An analysis of alternative risk measures. Academy of Management Journal, 33(4): 756-779.

Minichilli, A., Corbetta, G., \& MacMillan, I. C. 2010. Top management teams in familycontrolled companies: "Familiness", "faultlines", and their impact on financial performance. Journal of Management Studies, 47(2): 205-222.

Morck, R., Shleifer, A., \& Vishny, R. W. 1988. Management ownership and market valuation: An empirical analysis. Journal of Financial Economics, 20: 293-315.

Morck, R., Wolfenzon, D., \& Yeung, B. 2005. Corporate governance, economic entrenchment, and growth. Journal of Economic Literature, 43(3): 655-720.

Neubaum, D. O., Thomas, C. H., Dibrell, C., \& Craig, J. B. 2017. Stewardship climate scale: An assessment of reliability and validity. Family Business Review, 30(1): 37-60. 
Nixon, R. D., Hitt, M. A., Lee, H.-U., \& Jeong, E. 2004. Market reactions to announcements of corporate downsizing actions and implementation strategies. Strategic Management Journal, 25(11): 1121-1129.

Nyberg, A. 2010. Retaining your high performers: Moderators of the performance-job satisfaction-voluntary turnover relationship. Journal of Applied Psychology, 95(3): 440453.

Osterman, P. 2006. The wage effects of high performance work organization in manufacturing. ILR Review, 59(2): 187-204.

Patel, P. C., \& Chrisman, J. J. 2014. Risk abatement as a strategy for R\&D investments in family firms: Research notes and commentaries. Strategic Management Journal, 35(4): 617627.

Pearson, A. W., \& Marler, L. E. 2010. A leadership perspective of reciprocal stewardship in family firms. Entrepreneurship Theory and Practice, 34(6): 1117-1124.

Pérez-González, F. 2006. Inherited control and firm performance. The American Economic Review, 96(5): 1559-1588.

Pittino, D., Visintin, F., Lenger, T., \& Sternad, D. 2016. Are high performance work practices really necessary in family SMEs? An analysis of the impact on employee retention. Journal of Family Business Strategy, 7(2): 75-89.

Price, J. L., \& Mueller, C. W. 1981. A Causal Model of Turnover for Nurses. The Academy of Management Journal, 24(3): 543-565.

Reid, R. S., \& Harris, R. I. D. 2002. The determinants of training in SMEs in Northern Ireland. Education \& Training, 44(8/9): 443-450.

Samuelson, P. A., \& Nordhaus, W. D. 1989. Economics (13th). McGraw-Hill, New York, NY.

Schulze, W. S., Lubatkin, M. H., \& Dino, R. N. 2003. Exploring the agency consequences of ownership dispersion among the directors of private family firms. Academy of Management Journal, 46(2): 179-194.

Schulze, W. S., Lubatkin, M. H., Dino, R. N., \& Buchholtz, A. K. 2001. Agency relationships in family firms: Theory and evidence. Organization Science, 12(2): 99-116.

Schulze, W. S., \& Zellweger, T. M. 2016. Is owner-management costly. Working Paper, University of Utah, University of St. Gallen.

Segal, L., \& Lehrer, M. 2012. The institutionalization of stewardship: Theory, propositions, and insights from change in the edmonton public schools. Organization Studies, 33(2): 169201.

Shaw, J. D., Delery, J. E., Jenkins, G. D., \& Gupta, N. 1998. An organization-level analysis of voluntary and involuntary turnover. Academy of Management Journal, 41(5): 511-525.

Shaw, J. D., Gupta, N., \& Delery, J. E. 2005. Alternative conceptualizations of the relationship between voluntary turnover and organizational performance. Academy of Management Journal, 48(1): 50-68.

Sieger, P., Zellweger, T., \& Aquino, K. 2013. Turning agents into psychological principals: Aligning interests of non-owners through psychological ownership. Journal of Management Studies, 50(3): 361-388.

Simon, H. A. 1957. The compensation of executives. Sociometry, 20(1): 32-35.

Sraer, D., \& Thesmar, D. 2007. Performance and behavior of family firms: Evidence from the French stock market. Journal of the European Economic Association, 5(4): 709-751.

Steinherr, A. 1977. On the efficiency of profit sharing and labor participation in management. The Bell Journal of Economics, 8(2): 545-555. 
Sundaramurthy, C., \& Lewis, M. 2003. Control and collaboration: Paradoxes of governance. Academy of Management Review, 28(3): 397-415.

Trevor, C. O., Gerhart, B., \& Boudreau, J. W. 1997. Voluntary turnover and job performance: Curvilinearity and the moderating influences of salary growth and promotions. Journal of Applied Psychology, 82(1): 44-61.

Trevor, C. O., \& Nyberg, A. J. 2008. Keeping your headcount when all about you are losing theirs: Downsizing, voluntary turnover rates, and the moderating role of HR practices. Academy of Management Journal, 51(2): 259-276.

Vallejo, M. C. 2009. The effects of commitment of non-family employees of family firms from the perspective of stewardship theory. Journal of Business Ethics, 87(3): 379-390.

van Essen, M., Strike, V. M., Carney, M., \& Sapp, S. 2015. The resilient family firm: Stakeholder outcomes and institutional effects. Corporate Governance: An International Review, 23(3): 167-183.

van Essen, M., van Oosterhout, H., \& Heugens, P. P. M. A. R. 2013. Competition and cooperation in corporate governance: The effects of labor institutions on blockholder effectiveness in 23 European countries. Organization Science, 24(2): 530-551.

Vardaman, J. M., Allen, D. G., Otondo, R. F., Hancock, J. I., Shore, L. M., et al. 2016. Social comparisons and organizational support: Implications for commitment and retention. Human Relations, 69(7): 1483-1505.

Verbeke, A., \& Kano, L. 2012. The transaction cost economics theory of the family firm: Family-based human asset specificity and the bifurcation bias. Entrepreneurship Theory and Practice, 36(6): 1183-1205.

Villalonga, B., \& Amit, R. 2006. How do family ownership, control and management affect firm value? Journal of Financial Economics, 80(2): 385-417.

Villalonga, B., \& Amit, R. 2009. How are U.S. family firms controlled? The Review of Financial Studies, 22(8): 3047-3091.

Volpin, P. F. 2002. Governance with poor investor protection: evidence from top executive turnover in Italy. Journal of Financial Economics, 64(1): 61-90.

Vroom, V. 1964. Work and motivation. New York: John Wiley \& Sons.

Wagner, J. 1997. Firm size and job quality: a survey of the evidence from Germany? Small Business Economics, 9(5): 411-425.

Wall, R. A. 1998. An empirical investigation of the production function of the family firm. Journal of Small Business Management, 36(2): 24.

Wasserman, N. 2006. Stewards, agents, and the founder discount: Executive compensation in new ventures. Academy of Management Journal, 49(5): 960-976.

Werner, S., Tosi, H. L., \& Gómez-Mejía, L. 2005. Organizational governance and employee pay: how ownership structure affects the firm's compensation strategy. Strategic Management Journal, 26(4): 377-384.

Westhead, P., \& Cowling, M. 1998. Family firm research: The need for a methodological rethink. Entrepreneurship Theory and Practice, 23(1): 31-33.

Wilson, N., Wright, M., \& Scholes, L. 2013. Family business survival and the role of boards. Entrepreneurship Theory and Practice, 37(6): 1369-1389.

Wiseman, R. M., Cuevas-Rodríguez, G., \& Gomez-Mejia, L. R. 2012. Towards a social theory of agency. Journal of Management Studies, 49(1): 202-222.

Wright, P. M., \& McMahan, G. C. 1992. Theoretical perspectives for strategic human resource management. Journal of Management, 18(2): 295-320. 
Young, M. N., Peng, M. W., Ahlstrom, D., Bruton, G. D., \& Jiang, Y. 2008. Corporate governance in emerging economies: A review of the principal-principal perspective. Journal of Management Studies, 45(1): 196-220.

Zahra, S. A. 2003. International expansion of U.S. manufacturing family businesses: The effect of ownership and involvement. Journal of Business Venturing, 18(4): 495-512.

Zahra, S. A., Hayton, J. C., Neubaum, D. O., Dibrell, C., \& Craig, J. 2008. Culture of family commitment and strategic flexibility: The moderating effect of stewardship. Entrepreneurship Theory and Practice, 32(6): 1035-1054.

Zellweger, T. 2007. Time horizon, costs of equity capital, and generic investment strategies of firms. Family Business Review, 20(1): 1-15.

Zellweger, T., \& Kammerlander, N. 2015. Family, wealth, and governance: An agency account. Entrepreneurship Theory and Practice, 39(6): 1281-1303.

Zellweger, T. M., Kellermanns, F. W., Chrisman, J. J., \& Chua, J. H. 2012. Family control and family firm valuation by family CEOs: The importance of intentions for transgenerational control. Organization Science, 23(3): 851-868.

Zellweger, T. M., Nason, R. S., Nordqvist, M., \& Brush, C. G. 2013. Why do family firms strive for nonfinancial goals? An organizational identity perspective. Entrepreneurship Theory and Practice, 37(2): 229-248. 


\section{Table 1 - Descriptive statistics and Correlations}

\begin{tabular}{|c|c|c|c|c|c|c|c|c|c|c|c|c|c|c|c|c|c|c|c|}
\hline & Mean & s.d. & 1 & 2 & 3 & 4 & 5 & 6 & 7 & 8 & 9 & 10 & 11 & 12 & 13 & 14 & 15 & 16 & 17 \\
\hline 1Financial stewardship & 0.00 & 1.00 & & & & & & & & & & & & & & & & & \\
\hline 2Compensation & 26.53 & 9.11 & -0.04 & & & & & & & & & & & & & & & & \\
\hline 3Off-Site Training & 0.20 & 0.35 & -0.02 & 0.29 & & & & & & & & & & & & & & & \\
\hline 4Dismissals & 0.04 & 0.07 & 0.01 & 0.03 & -0.04 & & & & & & & & & & & & & & \\
\hline 5 Voluntary turnover & 0.16 & 0.17 & 0.01 & -0.08 & -0.04 & 0.08 & & & & & & & & & & & & & \\
\hline 6Labor productivity & 75.24 & 54.63 & -0.02 & 0.19 & 0.11 & -0.02 & -0.03 & & & & & & & & & & & & \\
\hline 7Family firm & 0.23 & 0.42 & 0.02 & -0.22 & -0.11 & -0.02 & 0.00 & -0.09 & & & & & & & & & & & \\
\hline 8Family board involvement & 0.11 & 0.27 & 0.02 & -0.20 & -0.10 & -0.02 & -0.02 & -0.05 & 0.77 & & & & & & & & & & \\
\hline 9Family-firm identity overlap & 0.11 & 0.31 & 0.01 & -0.16 & -0.08 & -0.02 & 0.00 & -0.04 & 0.65 & 0.41 & & & & & & & & & \\
\hline 10Male & 0.71 & 0.25 & 0.02 & -0.02 & -0.02 & -0.02 & -0.15 & -0.02 & 0.16 & 0.12 & 0.15 & & & & & & & & \\
\hline 11Blue collar & 0.45 & 0.35 & 0.01 & -0.50 & -0.19 & -0.07 & -0.08 & -0.15 & 0.24 & 0.20 & 0.20 & 0.44 & & & & & & & \\
\hline 12Permanent contracts & 0.97 & 0.07 & -0.01 & 0.12 & 0.03 & 0.03 & -0.17 & 0.02 & 0.02 & 0.01 & 0.04 & 0.12 & -0.01 & & & & & & \\
\hline 13Education & 0.29 & 0.31 & 0.01 & 0.56 & 0.26 & -0.02 & 0.00 & 0.14 & -0.23 & -0.21 & -0.20 & -0.28 & -0.65 & 0.04 & & & & & \\
\hline 14Firm age & 25.89 & 18.81 & -0.09 & 0.06 & 0.05 & -0.05 & -0.07 & 0.11 & 0.04 & 0.03 & 0.02 & 0.01 & 0.02 & 0.02 & -0.03 & & & & \\
\hline 15Firm size & 88.01 & 141.82 & -0.05 & 0.13 & 0.26 & 0.03 & 0.12 & -0.06 & -0.03 & -0.07 & -0.05 & 0.06 & 0.11 & -0.11 & 0.07 & 0.14 & & & \\
\hline 16Firm growth & 0.05 & 0.33 & 0.09 & -0.04 & 0.02 & 0.02 & 0.04 & -0.04 & -0.03 & -0.02 & -0.02 & -0.01 & -0.02 & -0.04 & 0.01 & -0.11 & 0.03 & & \\
\hline 17Capital intensity & 138.15 & 348.36 & -0.10 & 0.11 & 0.07 & -0.03 & 0.00 & 0.04 & 0.06 & 0.02 & 0.02 & 0.00 & -0.02 & 0.01 & 0.02 & 0.08 & -0.01 & -0.05 & \\
\hline 18Flanders & 0.67 & 0.47 & 0.01 & -0.04 & -0.02 & -0.02 & -0.04 & -0.01 & 0.03 & 0.01 & 0.05 & 0.06 & 0.09 & 0.15 & -0.09 & -0.03 & -0.01 & 0.00 & 0.00 \\
\hline
\end{tabular}

\section{Notes.}

$N=102,094$ firm-years for all variables except Off-Site Training and Education which were only available after $2008(N=34,747$ for these variables); s.d. standard deviation 
Table 2 - Mean Comparison Tests (Full Sample)

\begin{tabular}{|c|c|c|c|c|c|c|c|}
\hline & \multicolumn{2}{|c|}{ Family firms } & \multicolumn{2}{|c|}{ Nonfamily firms } & \multicolumn{3}{|c|}{ Family firms - Nonfamily firms } \\
\hline & Mean & s.d. & Mean & s.d. & Contrast & s.e. & $\mathrm{p}$ \\
\hline Financial stewardship & 0.03 & 0.86 & -0.01 & 1.04 & $0.04 * * *$ & 0.01 & 0.00 \\
\hline Compensation & 22.92 & 5.63 & 27.61 & 9.66 & $-4.70 * * *$ & 0.07 & 0.00 \\
\hline Off-Site Training & 0.14 & 0.26 & 0.24 & 0.37 & $-0.10 * * *$ & 0.00 & 0.00 \\
\hline Dismissals & 0.04 & 0.06 & 0.04 & 0.07 & $-0.00 * * *$ & 0.00 & 0.00 \\
\hline Voluntary turnover & 0.16 & 0.17 & 0.16 & 0.17 & 0.00 & 0.00 & 0.36 \\
\hline Labor productivity & 62.59 & 46.34 & 79.05 & 56.33 & $-16.45 * * *$ & 0.41 & 0.00 \\
\hline Family board involvement & 0.50 & 0.36 & 0.00 & 0.00 & $0.50 * * *$ & 0.00 & 0.00 \\
\hline Family-firm identity overlap & 0.49 & 0.50 & 0.00 & 0.00 & $0.49 * * *$ & 0.00 & 0.00 \\
\hline Male & 0.79 & 0.22 & 0.69 & 0.25 & $0.09 * * *$ & 0.00 & 0.00 \\
\hline Blue collar & 0.61 & 0.30 & 0.40 & 0.35 & $0.20 * * *$ & 0.00 & 0.00 \\
\hline Permanent contracts & 0.97 & 0.07 & 0.97 & 0.08 & $0.00 * * *$ & 0.00 & 0.00 \\
\hline Educational level & 0.16 & 0.22 & 0.33 & 0.32 & $-0.17 * * *$ & 0.00 & 0.00 \\
\hline Firm age & 27.16 & 17.82 & 25.51 & 19.09 & $1.66^{* * *}$ & 0.14 & 0.00 \\
\hline Firm size & 69.85 & 102.17 & 93.47 & 151.30 & $-23.62 * * *$ & 1.06 & 0.00 \\
\hline Firm growth & 0.03 & 0.27 & 0.05 & 0.34 & $-0.02 * * *$ & 0.00 & 0.00 \\
\hline Capital intensity & 116.35 & 280.52 & 144.70 & 366.05 & $-28.36^{* * *}$ & 2.62 & 0.00 \\
\hline Flanders & 0.69 & 0.46 & 0.66 & 0.47 & $0.03 * * *$ & 0.00 & 0.00 \\
\hline
\end{tabular}

Notes.

$N=102,094$ firm-years for all variables except Off-Site Training and Educational level which were only available after 2008 ( $N=34,747$ for these variables). s.d. standard deviation; s.e. standard error

$* p<0.05$

$* * p<0.01$

$* * * p<0.001$ 
Table 3 - Propensity Score Matching Estimates (1996-2014)

Panel A - Standard set of matching covariates

\begin{tabular}{lrrrrrrr}
\hline & \multicolumn{2}{c}{ Family firms } & \multicolumn{2}{c}{ Nonfamily firms } & \multicolumn{2}{c}{ Family firms - Nonfamily firms } \\
\cline { 2 - 8 } & Mean & \multicolumn{1}{c}{ s.d. } & Mean & \multicolumn{1}{c}{ s.d. } & Contrast & s.e. & $\mathrm{p}$ \\
\hline Financial stewardship & 0.028 & 0.857 & -0.034 & 0.957 & $0.062^{* * *}$ & 0.009 & 0.00 \\
Compensation $^{\mathrm{a}}$ & 22.921 & 5.645 & 24.818 & 7.850 & $-1.896^{* * *}$ & 0.064 & 0.00 \\
Off-site training $^{\mathrm{b}}$ & 0.145 & 0.272 & 0.167 & 0.304 & $-0.022^{* * *}$ & 0.005 & 0.00 \\
Dismissals $^{\mathrm{a}}$ & 0.042 & 0.064 & 0.042 & 0.064 & -0.001 & 0.001 & 0.78 \\
Voluntary turnover $_{\text {Labor Productivity }}$ & 0.155 & 0.171 & 0.143 & 0.166 & $0.014 * * *$ & 0.002 & 0.00 \\
\hline
\end{tabular}

$\underline{\text { Panel B - Financial stewardship as additional matching covariate }}$

\begin{tabular}{lrrrrrrr}
\hline & \multicolumn{2}{c}{ Family firms } & \multicolumn{2}{c}{ Nonfamily firms } & \multicolumn{2}{c}{ Family firms - Nonfamily firms } \\
\cline { 2 - 8 } & Mean & \multicolumn{1}{c}{ s.d. } & Mean & \multicolumn{1}{c}{ s.d. } & Contrast & s.e. & $\mathrm{p}$ \\
\hline Compensation $^{\mathrm{a}}$ & 22.915 & 5.659 & 24.715 & 7.682 & $-1.800^{* * *}$ & 0.068 & 0.00 \\
Off-site training $^{\mathrm{b}}$ & 0.121 & 0.253 & 0.140 & 0.286 & $-0.019^{* * *}$ & 0.004 & 0.00 \\
Dismissals $^{\mathrm{a}}$ & 0.041 & 0.064 & 0.042 & 0.065 & -0.001 & 0.001 & 0.18 \\
Voluntary turnover $^{\text {Labor Productivity }}$ & 0.155 & 0.172 & 0.141 & 0.165 & $0.014 * * *$ & 0.002 & 0.00 \\
\hline
\end{tabular}

Panel C - Financial stewardship, compensation and dismissals as additional matching covariates

\begin{tabular}{lrrrrrrr}
\hline & \multicolumn{2}{c}{ Family firms } & \multicolumn{2}{c}{ Nonfamily firms } & \multicolumn{3}{c}{ Family firms - Nonfamily firms } \\
\cline { 2 - 8 } & Mean & s.d. & Mean & s.d. & Contrast & s.e. & p \\
\hline Voluntary turnover & 0.155 & 0.172 & 0.145 & 0.170 & $0.009^{* * *}$ & 0.002 & 0.00 \\
Labor Productivity & 65.799 & 45.629 & 68.057 & 47.065 & $-2.259^{* * *}$ & 0.466 & 0.00 \\
\hline
\end{tabular}

Notes.

All models include matching covariates for Male, Blue collar, Permanent contracts, Firm age, Firm size, Firm growth, Capital intensity, Region, Industry and Year. s.d. standard deviation; s.e. standard error

${ }^{\text {a }}$ To control for the potential influence of HR-bundles, Dismissals was added as matching covariate in the models for Compensation; and Compensation in the models for Dismissals

${ }^{\mathrm{b}}$ Because firms were only required to publish information regarding their training initiatives as from 2008, the time frame for Off-site training was 2008-2014. Compensation and Dismissals were added as matching covariates in these models to control for the potential influence of HR-bundles.

\footnotetext{
$* p<0.05$

$* * p<0.01$

$* * * p<0.001$
} 
Table 4 - Random-effects Maximum Likelihood Regressions for the Moderation Effect of Firm age, Family board involvement and Family-firm identity overlap (1996-2014)

\begin{tabular}{|c|c|c|c|c|c|c|}
\hline & $\begin{array}{c}\text { Financial } \\
\text { stewardship }\end{array}$ & Compensation & $\begin{array}{l}\text { Off-site } \\
\text { training }\end{array}$ & Dismissals & $\begin{array}{l}\text { Voluntary } \\
\text { turnover }\end{array}$ & $\begin{array}{c}\text { Labor } \\
\text { productivity }\end{array}$ \\
\hline \multirow[t]{2}{*}{ Firm age $t-1$} & $-0.002 * * *$ & $0.037 * * *$ & 0.000 & $-0.000 * * *$ & $-0.001 * * *$ & 0.001 \\
\hline & $(0.001)$ & $(0.004)$ & $(0.000)$ & $(0.000)$ & $(0.000)$ & $(0.001)$ \\
\hline \multirow[t]{2}{*}{ Firm size $_{t-1}$} & $-0.104 * * *$ & $0.298 * * *$ & $0.072 * * *$ & $0.004 * * *$ & $0.023 * * *$ & -0.001 \\
\hline & $(0.004)$ & $(0.034)$ & $(0.003)$ & $(0.000)$ & $(0.001)$ & $(0.006)$ \\
\hline \multirow[t]{2}{*}{ Capital intensityt-1 } & $-0.131 * * *$ & $0.087 * * *$ & $0.010 * * *$ & $-0.000+$ & $0.002 * *$ & $0.042 * * *$ \\
\hline & $(0.003)$ & $(0.018)$ & $(0.002)$ & $(0.000)$ & $(0.001)$ & $(0.004)$ \\
\hline \multirow[t]{2}{*}{ Flanders } & 0.021 & -0.201 & -0.002 & $-0.005^{* * *}$ & -0.001 & 0.018 \\
\hline & $(0.015)$ & $(0.143)$ & $(0.006)$ & $(0.001)$ & $(0.003)$ & $(0.020)$ \\
\hline \multirow[t]{2}{*}{ Male $_{\mathrm{t}-1}$} & & $2.994 * * *$ & $0.051 * * *$ & $-0.008 * * *$ & $-0.043 * * *$ & -0.043 \\
\hline & & $(0.199)$ & $(0.015)$ & $(0.002)$ & $(0.006)$ & $(0.036)$ \\
\hline \multirow[t]{2}{*}{ Blue collar $\mathrm{t}_{\mathrm{-}}$} & & $-8.766^{* * *}$ & $-0.106 * * *$ & -0.002 & $-0.026^{* * *}$ & $-0.366 * * *$ \\
\hline & & $(0.149)$ & $(0.012)$ & $(0.002)$ & $(0.004)$ & $(0.028)$ \\
\hline \multirow[t]{2}{*}{ Permanent contracts $\mathrm{t}-1$} & & $4.691 * * *$ & $0.094 * *$ & $0.016^{* * *}$ & $-0.260 * * *$ & 0.027 \\
\hline & & $(0.293)$ & $(0.033)$ & $(0.004)$ & $(0.011)$ & $(0.062)$ \\
\hline \multirow[t]{2}{*}{ Firm growtht-1 } & & $-0.362 * * *$ & -0.010 & 0.001 & $-0.004 *$ & -0.008 \\
\hline & & $(0.051)$ & $(0.009)$ & $(0.001)$ & $(0.002)$ & $(0.011)$ \\
\hline \multirow[t]{2}{*}{ Compensation $^{\mathrm{a}}$} & & & $0.006 * * *$ & $0.000^{* * *}$ & $-0.002 * * *$ & $0.016^{* * *}$ \\
\hline & & & $(0.000)$ & $(0.000)$ & $(0.000)$ & $(0.001)$ \\
\hline \multirow[t]{2}{*}{ Dismissals $^{\mathrm{a}}$} & & $4.646 * * *$ & $-0.113 * * *$ & & $0.050 * * *$ & $-0.333 * * *$ \\
\hline & & $(0.237)$ & $(0.030)$ & & $(0.009)$ & $(0.054)$ \\
\hline \multirow[t]{2}{*}{ Financial stewardship $\mathrm{t}-1$} & & $-0.042 *$ & -0.002 & $0.001 * * *$ & $0.002 * *$ & $0.014 * *$ \\
\hline & & $(0.020)$ & $(0.002)$ & $(0.000)$ & $(0.001)$ & $(0.004)$ \\
\hline \multirow[t]{2}{*}{ Family Firm } & $0.095 * *$ & $-2.145 * * *$ & -0.018 & $0.004 *$ & $0.020 * *$ & $-0.281 * * *$ \\
\hline & $(0.035)$ & $(0.322)$ & $(0.014)$ & $(0.002)$ & $(0.006)$ & $(0.046)$ \\
\hline \multirow[t]{2}{*}{ Family board involvement } & -0.018 & $-0.763+$ & -0.007 & $-0.006^{*}$ & $-0.027 * * *$ & $0.176 * *$ \\
\hline & $(0.044)$ & $(0.413)$ & $(0.018)$ & $(0.003)$ & $(0.008)$ & $(0.058)$ \\
\hline \multirow[t]{2}{*}{ Family-firm identity overlap } & -0.048 & -0.168 & -0.015 & $-0.006 * *$ & -0.002 & $0.132 * *$ \\
\hline & $(0.032)$ & $(0.302)$ & $(0.013)$ & $(0.002)$ & $(0.006)$ & $(0.042)$ \\
\hline \multirow[t]{2}{*}{ Firm age $_{\mathrm{t}-1} \times$ Family Firm } & -0.000 & $-0.032 * *$ & $-0.001 *$ & -0.000 & -0.000 & -0.002 \\
\hline & $(0.001)$ & $(0.011)$ & $(0.001)$ & $(0.000)$ & $(0.000)$ & $(0.002)$ \\
\hline \multirow{3}{*}{$\begin{array}{l}\text { Firm age } t-1 \times \text { Family board } \\
\text { involvement }\end{array}$} & & & & & & \\
\hline & -0.000 & $-0.053 * * *$ & 0.001 & 0.000 & 0.000 & 0.004 \\
\hline & $(0.002)$ & $(0.015)$ & $(0.001)$ & $(0.000)$ & $(0.000)$ & $(0.003)$ \\
\hline \multirow{3}{*}{$\begin{array}{l}\text { Firm age } t-1 \times \text { Family-firm } \\
\text { identity overlap }\end{array}$} & & & & & & \\
\hline & -0.000 & $-0.038 * * *$ & 0.000 & 0.000 & $0.001 *$ & 0.003 \\
\hline & $(0.001)$ & $(0.011)$ & $(0.001)$ & $(0.000)$ & $(0.000)$ & $(0.002)$ \\
\hline \multirow[t]{2}{*}{ Intercept } & $1.192 * * *$ & $15.975 * * *$ & $-0.597 * * *$ & $0.015^{*}$ & $0.414 * * *$ & $3.264 * * *$ \\
\hline & $(0.088)$ & $(0.916)$ & $(0.055)$ & $(0.007)$ & $(0.020)$ & $(0.133)$ \\
\hline Industry effects & Included & Included & Included & Included & Included & Included \\
\hline Year effects & Included & Included & Included & Included & Included & Included \\
\hline Chi-squared & $4210.78 * * *$ & $17984.08 * * *$ & 6853.86 *** & $1689.25^{* * *}$ & $3793.68 * * *$ & $3410.19^{* * *}$ \\
\hline $\mathrm{p}$ & 0.000 & 0.000 & 0.000 & 0.000 & 0.000 & 0.000 \\
\hline \multicolumn{7}{|l|}{ Notes. } \\
\hline \multicolumn{7}{|l|}{$* p<0.05$} \\
\hline \multicolumn{7}{|l|}{$* * p<0.01$} \\
\hline$* * * p<0.001$ & & & & & & \\
\hline${ }^{a}$ To control for the poten & luence of $H$ & -bundles, Dis & hissals was & dded as a & ontrol in the & lels \\
\hline for Compensation and $O$ & training, an & Compensatio & was added & as a contro & in the mode & Off- \\
\hline site training and Dismiss & the models & or Voluntary & Irnover and & abor prod & ctivity, Disn & \\
\hline
\end{tabular}


Table 5 - Robustness test: Propensity Score Matched Estimates including Education as an additional matching covariate (Restricted Time Period 2008-2014)

Panel A - Standard set of matching covariates

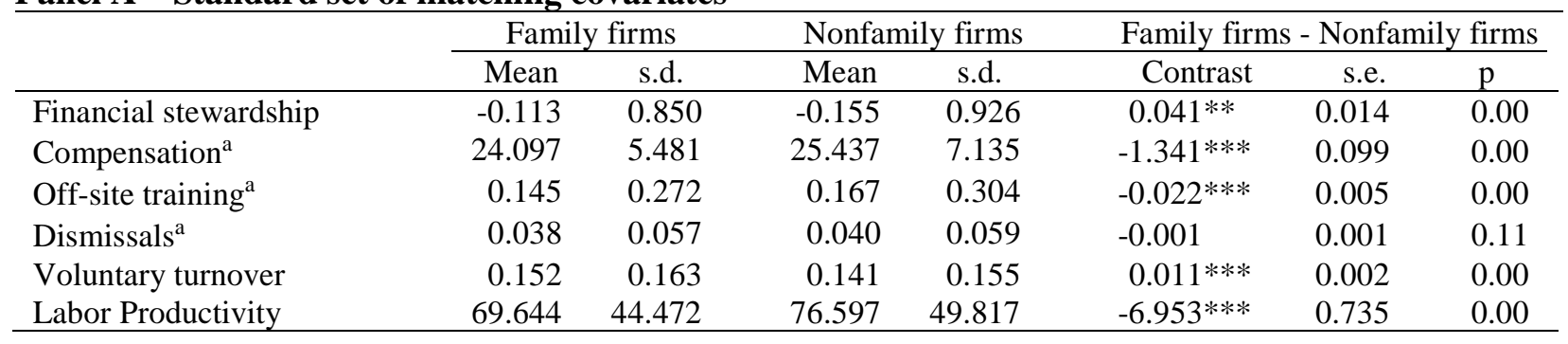

Panel B - Financial stewardship as additional matching covariate

\begin{tabular}{lrrrrrrr}
\hline & \multicolumn{2}{c}{ Family firms } & \multicolumn{2}{c}{ Nonfamily firms } & \multicolumn{2}{c}{ Family firms - Nonfamily firms } \\
\cline { 2 - 8 } & Mean & \multicolumn{1}{c}{ s.d. } & Mean & s.d. & Contrast & s.e. & $\mathrm{p}$ \\
\hline Compensation $^{\mathrm{a}}$ & 24.064 & 5.428 & 25.535 & 7.119 & $-1.471^{* * *}$ & 0.102 & 0.00 \\
Off-site training $^{\mathrm{a}}$ & 0.121 & 0.253 & 0.140 & 0.286 & $-0.019^{* * *}$ & 0.004 & 0.00 \\
Dismissals $^{\mathrm{a}}$ & 0.039 & 0.057 & 0.041 & 0.061 & $-0.003^{* *}$ & 0.001 & 0.01 \\
Voluntary turnover $_{\text {Labor Productivity }}$ & 0.150 & 0.160 & 0.139 & 0.155 & $0.011^{* * *}$ & 0.003 & 0.00 \\
& 72.031 & 43.659 & 77.338 & 48.121 & $-5.307 * * *$ & 0.739 & 0.00 \\
\hline
\end{tabular}

Panel C - Financial stewardship, compensation, off-site training and dismissals as additional matching covariates

\begin{tabular}{lrrrrrrr}
\hline & \multicolumn{3}{c}{ Family firms } & \multicolumn{3}{c}{ Nonfamily firms } & \multicolumn{3}{c}{ Family firms - Nonfamily firms } \\
\cline { 2 - 8 } & Mean & s.d. & Mean & s.d. & Contrast & s.e. & $\mathrm{p}$ \\
\hline Voluntary turnover & 0.150 & 0.160 & 0.144 & 0.158 & $0.006^{*}$ & 0.003 & 0.03 \\
Labor Productivity & 72.031 & 43.659 & 74.017 & 44.368 & $-1.986^{* * *}$ & 0.708 & 0.00 \\
\hline
\end{tabular}

Notes.

All models included matching covariates for Education, Male, Blue collar, Permanent contracts, Firm age, Firm size, Firm growth, Capital intensity, Region, Industry and Year. s.d. standard deviation; s.e. standard error

${ }^{a}$ To control for the potential influence of HR-bundles, Dismissals and Off-site training were added as matching covariates in the model for Compensation, Compensation and Off-site training in the model for Dismissals, and Compensation and Dismissals in the model for Off-site training.

Balancing test for matching are available in Appendix A.

$* p<0.05$
$* * p<0.01$
$* * * p<0.001$ 
Table 6: Robustness test: Random effects Maximum Likelihood Regressions (1996-2014)

\section{Panel A: Financial stewardship, Compensation, Off-site training and Dismissals}

\begin{tabular}{|c|c|c|c|c|c|c|c|}
\hline \multirow[b]{2}{*}{ Firm age $_{t-1}$} & \multirow{2}{*}{$\begin{array}{c}\begin{array}{c}\text { Financial } \\
\text { stewardship }\end{array} \\
-0.002 * * * \\
(0.000)\end{array}$} & \multicolumn{2}{|c|}{ Compensation } & \multicolumn{2}{|c|}{ Off-site training } & \multicolumn{2}{|c|}{ Dismissals } \\
\hline & & $\begin{array}{l}0.030^{* * * *} \\
(0.004)\end{array}$ & $\begin{array}{l}0.028^{* * * *} \\
(0.004)\end{array}$ & $\begin{array}{l}-0.000 \\
(0.000)\end{array}$ & $\begin{array}{l}-0.000 \\
(0.000)\end{array}$ & $\begin{array}{l}-0.000 * * * \\
(0.000)\end{array}$ & $\begin{array}{l}-0.000 * * * \\
(0.000)\end{array}$ \\
\hline Firm size $t_{-1}$ & $\begin{array}{l}-0.095 * * * \\
(0.006)\end{array}$ & $\begin{array}{l}0.307 * * * \\
(0.033)\end{array}$ & $\begin{array}{l}0.358 * * * \\
(0.036)\end{array}$ & $\begin{array}{l}0.071 * * * \\
(0.003)\end{array}$ & $\begin{array}{l}0.071 * * * \\
(0.003)\end{array}$ & $\begin{array}{l}0.004 * * * \\
(0.000)\end{array}$ & $\begin{array}{l}0.004 * * * \\
(0.000)\end{array}$ \\
\hline Capital intensity $\mathrm{t}-1$ & $\begin{array}{l}-0.127 * * * \\
(0.004)\end{array}$ & $\begin{array}{c}0.033^{*} \\
(0.017)\end{array}$ & $\begin{array}{l}0.069^{* * *} \\
(0.019)\end{array}$ & $\begin{array}{l}0.009 * * * \\
(0.002)\end{array}$ & $\begin{array}{l}0.009 * * * \\
(0.002)\end{array}$ & $\begin{array}{l}-0.001 * \\
(0.000)\end{array}$ & $\begin{array}{l}-0.000 \\
(0.000)\end{array}$ \\
\hline Flanders & $\begin{array}{c}0.036^{*} \\
(0.018)\end{array}$ & $\begin{array}{l}-0.255+ \\
(0.136)\end{array}$ & $\begin{array}{l}-0.263+ \\
(0.146)\end{array}$ & $\begin{array}{c}0.000 \\
(0.006)\end{array}$ & $\begin{array}{c}0.001 \\
(0.006)\end{array}$ & $\begin{array}{l}-0.004 * * * \\
(0.001)\end{array}$ & $\begin{array}{l}-0.004 * * * \\
(0.001)\end{array}$ \\
\hline Male $_{t-1}$ & & $\begin{array}{l}2.973 * * * \\
(0.188)\end{array}$ & $\begin{array}{l}2.869 * * * \\
(0.207)\end{array}$ & $\begin{array}{c}0.034^{*} \\
(0.015)\end{array}$ & $\begin{array}{l}0.045^{* *} \\
(0.016)\end{array}$ & $\begin{array}{l}-0.006 * * \\
(0.002)\end{array}$ & $\begin{array}{l}-0.006 * * \\
(0.002)\end{array}$ \\
\hline Blue collar $\mathrm{t}-1$ & & $\begin{array}{l}-8.787 * * * \\
(0.141)\end{array}$ & $\begin{array}{l}-8.949 * * * \\
(0.154)\end{array}$ & $\begin{array}{l}-0.113 * * * \\
(0.012)\end{array}$ & $\begin{array}{l}-0.105^{* * *} \\
(0.013)\end{array}$ & $\begin{array}{l}-0.002 \\
(0.002)\end{array}$ & $\begin{array}{l}-0.002 \\
(0.002)\end{array}$ \\
\hline Permanent contracts $\mathrm{t}-1$ & & $\begin{array}{l}5.044 * * * \\
(0.285)\end{array}$ & $\begin{array}{l}4.891 * * * \\
(0.317)\end{array}$ & $\begin{array}{l}0.093 * * \\
(0.032)\end{array}$ & $\begin{array}{l}0.094 * * \\
(0.035)\end{array}$ & $\begin{array}{l}0.017 * * * \\
(0.004)\end{array}$ & $\begin{array}{l}0.015^{* *} \\
(0.005)\end{array}$ \\
\hline Firm growth ${ }_{t-1}$ & & $\begin{array}{l}-0.387 * * * \\
(0.045)\end{array}$ & $\begin{array}{l}-0.404 * * * \\
(0.053)\end{array}$ & $\begin{array}{l}-0.010 \\
(0.008)\end{array}$ & $\begin{array}{l}-0.010 \\
(0.010)\end{array}$ & $\begin{array}{c}0.001 \\
(0.001)\end{array}$ & $\begin{array}{c}0.002+ \\
(0.001)\end{array}$ \\
\hline Compensation & & & & $\begin{array}{l}0.006^{* * * *} \\
(0.000)\end{array}$ & $\begin{array}{l}0.006^{* * * *} \\
(0.000)\end{array}$ & $\begin{array}{l}0.000 * * * \\
(0.000)\end{array}$ & $\begin{array}{l}0.000 * * * \\
(0.000)\end{array}$ \\
\hline Dismissals & & $\begin{array}{l}4.412 * * * \\
(0.231)\end{array}$ & $\begin{array}{l}4.450 * * * \\
(0.248)\end{array}$ & $\begin{array}{l}-0.110 * * * \\
(0.030)\end{array}$ & $\begin{array}{l}-0.111 * * * \\
(0.031)\end{array}$ & & \\
\hline Financial stewardship ${ }_{\mathrm{t}-1}$ & & & $\begin{array}{l}-0.043^{*} \\
(0.020)\end{array}$ & & $\begin{array}{l}-0.002 \\
(0.002)\end{array}$ & & $\begin{array}{l}0.001 * * \\
(0.000)\end{array}$ \\
\hline Family Firm & $\begin{array}{l}0.074 * * * \\
(0.020)\end{array}$ & $\begin{array}{l}-2.840 * * * \\
(0.160)\end{array}$ & $\begin{array}{l}-2.809 * * * \\
(0.168)\end{array}$ & $\begin{array}{l}-0.029 * * * \\
(0.007)\end{array}$ & $\begin{array}{l}-0.032 * * * \\
(0.007)\end{array}$ & $\begin{array}{l}-0.000 \\
(0.001)\end{array}$ & $\begin{array}{l}-0.001 \\
(0.001)\end{array}$ \\
\hline $\begin{array}{l}\text { Industry effects } \\
\text { Year effects }\end{array}$ & $\begin{array}{l}\text { Included } \\
\text { Included }\end{array}$ & $\begin{array}{l}\text { Included } \\
\text { Included }\end{array}$ & $\begin{array}{l}\text { Included } \\
\text { Included }\end{array}$ & $\begin{array}{l}\text { Included } \\
\text { Included }\end{array}$ & $\begin{array}{l}\text { Included } \\
\text { Included }\end{array}$ & $\begin{array}{l}\text { Included } \\
\text { Included }\end{array}$ & $\begin{array}{l}\text { Included } \\
\text { Included }\end{array}$ \\
\hline Chi-squared & $3957.3 * * *$ & $20302.3^{* * *}$ & $16278.9 * * *$ & $6755.1 * * *$ & $5840.0 * * *$ & $1735.9 * * *$ & $1526.7 * * *$ \\
\hline $\mathrm{p}$ & 0.000 & 0.000 & 0.000 & 0.000 & 0.000 & 0.000 & 0.000 \\
\hline
\end{tabular}

Notes.

$* p<0.05$
$* * p<0.01$
$* * * p<0.001$ 
Panel B: Voluntary turnover and Labor productivity

\begin{tabular}{|c|c|c|c|c|c|c|}
\hline \multirow{2}{*}{ Male $_{t-1}$} & \multicolumn{3}{|c|}{ Voluntary turnover } & \multicolumn{3}{|c|}{ Labor productivity } \\
\hline & $-0.054 * * *$ & $-0.055 * * *$ & $-0.044 * * *$ & -0.056 & -0.056 & $-0.093^{*}$ \\
\hline & $(0.007)$ & $(0.007)$ & $(0.006)$ & $(0.049)$ & $(0.049)$ & $(0.041)$ \\
\hline \multirow[t]{2}{*}{ Blue collar $\mathrm{t}-1$} & 0.004 & 0.004 & $-0.025 * * *$ & $-0.567 * * *$ & $-0.567 * * *$ & $-0.398 * * *$ \\
\hline & $(0.005)$ & $(0.005)$ & $(0.004)$ & $(0.035)$ & $(0.035)$ & $(0.031)$ \\
\hline \multirow[t]{2}{*}{ Permanent contracts $\mathrm{t}-1$} & $-0.297 * * *$ & $-0.297 * * *$ & $-0.267 * * *$ & 0.069 & 0.069 & -0.024 \\
\hline & $(0.013)$ & $(0.013)$ & $(0.011)$ & $(0.081)$ & $(0.081)$ & $(0.070)$ \\
\hline \multirow[t]{2}{*}{ Firm age $t_{t-1}$} & $-0.001 * * *$ & $-0.001 * * *$ & $-0.001 * * *$ & 0.000 & 0.000 & 0.001 \\
\hline & $(0.000)$ & $(0.000)$ & $(0.000)$ & $(0.001)$ & $(0.001)$ & $(0.001)$ \\
\hline \multirow[t]{2}{*}{ Firm size $_{t-1}$} & $0.016^{* * *}$ & $0.016^{* * *}$ & $0.023 * * *$ & $-0.020^{*}$ & $-0.020^{*}$ & -0.006 \\
\hline & $(0.001)$ & $(0.001)$ & $(0.001)$ & $(0.009)$ & $(0.009)$ & $(0.007)$ \\
\hline \multirow[t]{2}{*}{ Firm growth t-1 } & $0.006^{*}$ & $0.006+$ & $-0.004 *$ & $-0.042 *$ & $-0.043^{*}$ & -0.018 \\
\hline & $(0.003)$ & $(0.003)$ & $(0.002)$ & $(0.020)$ & $(0.020)$ & $(0.012)$ \\
\hline \multirow[t]{2}{*}{ Capital intensity $\mathrm{t}-1$} & -0.001 & -0.001 & $0.001 *$ & $0.045 * * *$ & $0.045 * * *$ & $0.037 * * *$ \\
\hline & $(0.001)$ & $(0.001)$ & $(0.001)$ & $(0.005)$ & $(0.005)$ & $(0.004)$ \\
\hline \multirow[t]{2}{*}{ Flanders } & -0.001 & -0.001 & 0.000 & 0.002 & 0.002 & 0.017 \\
\hline & $(0.003)$ & $(0.003)$ & $(0.003)$ & $(0.026)$ & $(0.026)$ & $(0.023)$ \\
\hline \multirow[t]{2}{*}{ Financial stewardship $\mathrm{t}_{\mathrm{t}-1}$} & & $0.002 * *$ & $0.002 * *$ & & 0.002 & 0.004 \\
\hline & & $(0.001)$ & $(0.001)$ & & $(0.005)$ & $(0.005)$ \\
\hline \multirow{2}{*}{ Compensation $_{\mathrm{t}-1}$} & & & $-0.002 * * *$ & & & $0.015 * * *$ \\
\hline & & & $(0.000)$ & & & $(0.001)$ \\
\hline \multirow[t]{2}{*}{ Dismissalst $_{\mathrm{t}-1}$} & & & $0.058 * * *$ & & & $-0.214 * * *$ \\
\hline & & & $(0.009)$ & & & $(0.056)$ \\
\hline \multirow[t]{2}{*}{ Family Firm } & $0.013 * * *$ & $0.013 * * *$ & $0.007 *$ & $-0.176^{* * *}$ & $-0.176^{* * *}$ & $-0.163 * * *$ \\
\hline & $(0.003)$ & $(0.003)$ & $(0.003)$ & $(0.029)$ & $(0.029)$ & $(0.026)$ \\
\hline \multirow[t]{2}{*}{ Intercept } & $0.461 * * *$ & $0.460 * * *$ & $0.432 * * *$ & $3.892 * * *$ & $3.891 * * *$ & $3.458 * * *$ \\
\hline & $(0.023)$ & $(0.023)$ & $(0.020)$ & $(0.183)$ & $(0.183)$ & $(0.159)$ \\
\hline Industry effects & Included & Included & Included & Included & Included & Included \\
\hline Year effects & Included & Included & Included & Included & Included & Included \\
\hline Chi-squared & $2739.77 * * *$ & $2747.03 * * *$ & $4030.35 * * *$ & $1954.88 * * *$ & $1955.04 * * *$ & $2873.66^{* * * *}$ \\
\hline $\mathrm{p}$ & 0.000 & 0.000 & 0.000 & 0.000 & 0.000 & 0.000 \\
\hline
\end{tabular}

Notes.

$* p<0.05$

$* * p<0.01$

$* * * p<0.001$ 


\section{Figure 1: Plots of Significant Interaction Effects}

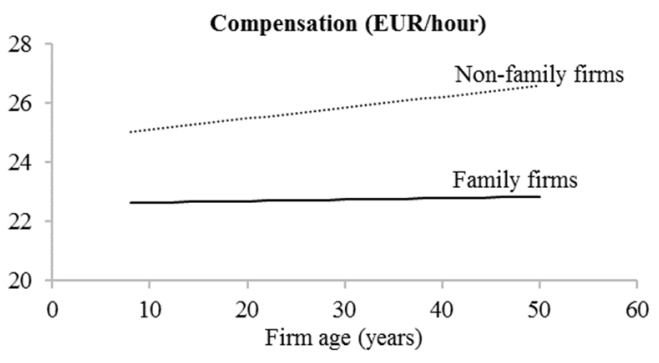

Figure 1(a): Interaction of Family firm and Firm age for Compensation

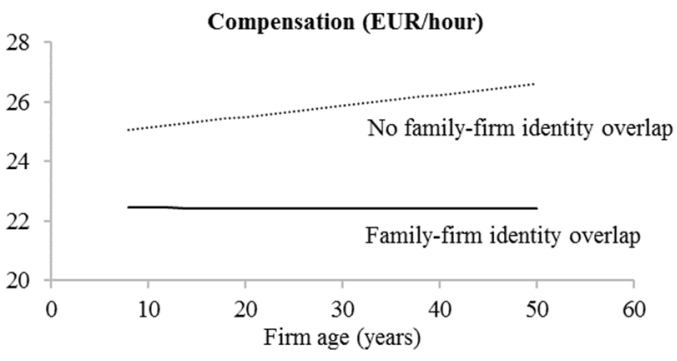

Figure 1(c): Interaction of Family-firm identity overlap and Firm age for Compensation

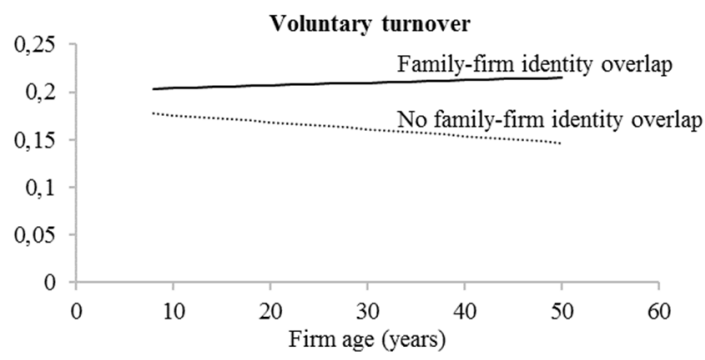

Figure 1(e): Interaction of Family-firm identity overlap and Firm age for Voluntary turnover

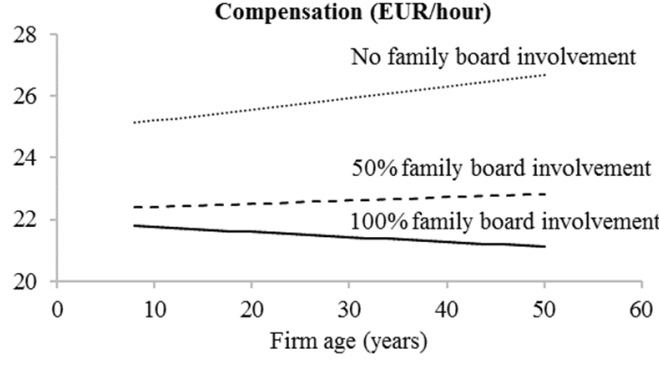

Figure 1(b): Interaction of Family board involvement and Firm age for Compensation

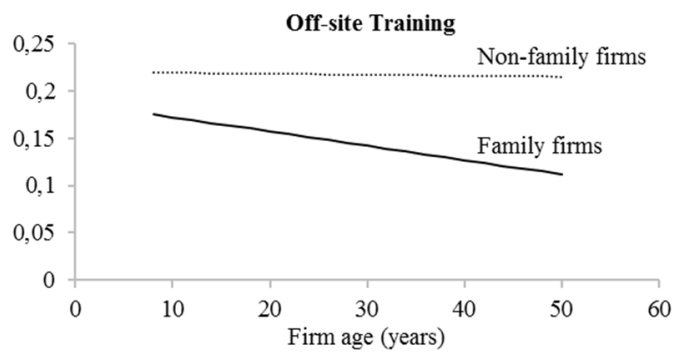

Figure 1(d): Interaction of Family firm and Firm age for Off-site Training 


\section{APPENDIX A}

\section{Balancing Tests}

To assess how well the propensity score matching procedure created comparable samples, we follow prior work (Chang \& Shim, 2015) and performed individual T-tests to compare the sample means of all variables included in each matching process between the family and nonfamily firm groups. We also used the propensity score histogram to verify whether the distribution of propensity scores was well balanced (Eggers \& Song, 2015).

The tables below show that there are no significant differences in all but two variables: Firm size and Blue collar. The effect sizes however are small, indicating that our samples are adequately well balanced. For instance, for the model with Compensation as the outcome variable, family firms have 0.9 percent more Blue collar and 1 employee less than nonfamily firms.

Note that observations were also matched based on industry classification and year. 


\section{Full time period (1996-2014)}

Financial stewardship

\begin{tabular}{|c|c|c|c|c|c|c|c|}
\hline & \multicolumn{2}{|c|}{ Family firms } & \multicolumn{2}{|c|}{ Nonfamily firms } & \multicolumn{3}{|c|}{ Family firms - Nonfamily firms } \\
\hline & Mean & s.d. & Mean & s.d. & Contrast & s.e. & $\mathrm{p}$ \\
\hline Financial stewardship & 0.028 & 0.857 & -0.034 & 1.005 & $0.062 * * *$ & 0.009 & 0.00 \\
\hline Matching co-variates & & & & & & & \\
\hline Firm age $(\ln )$ & 3.113 & 0.704 & 3.111 & 0.774 & 0.002 & 0.007 & 0.81 \\
\hline Firm size (ln) & 3.702 & 0.997 & 3.685 & 1.176 & 0.016 & 0.011 & 0.13 \\
\hline Capital intensity (ln) & 3.732 & 1.335 & 3.745 & 1.597 & -0.013 & 0.015 & 0.39 \\
\hline Flanders & 0.686 & 0.464 & 0.684 & 0.465 & 0.003 & 0.005 & 0.55 \\
\hline
\end{tabular}

$N=39,600$ firm-year observations (19,800 family firm observations and 19,800 nonfamily firm observations). s.d. standard deviation; s.e. standard error

\section{Compensation}

\begin{tabular}{|c|c|c|c|c|c|c|c|}
\hline & \multicolumn{2}{|c|}{ Family firms } & \multicolumn{2}{|c|}{ Nonfamily firms } & \multicolumn{3}{|c|}{ Family firms - Nonfamily firms } \\
\hline & Mean & s.d. & Mean & s.d. & Contrast & s.e. & $\mathrm{p}$ \\
\hline Compensation & 22.915 & 5.659 & 24.715 & 7.682 & $-1.800 * * *$ & 0.068 & 0.00 \\
\hline \multicolumn{8}{|l|}{ Matching co-variates } \\
\hline Financial stewardship & 0.028 & 0.857 & 0.027 & 0.956 & 0.001 & 0.009 & 0.93 \\
\hline Dismissals & 0.041 & 0.064 & 0.042 & 0.065 & -0.001 & 0.001 & 0.42 \\
\hline Male & 0.787 & 0.215 & 0.787 & 0.215 & -0.000 & 0.002 & 0.92 \\
\hline Blue collar & 0.608 & 0.295 & 0.618 & 0.302 & $-0.010 * *$ & 0.003 & 0.00 \\
\hline Permanent contracts & 0.972 & 0.070 & 0.973 & 0.067 & -0.000 & 0.001 & 0.70 \\
\hline Firm age $(\ln )$ & 3.113 & 0.704 & 3.105 & 0.757 & 0.008 & 0.007 & 0.27 \\
\hline Firm size $(\ln )$ & 3.700 & $0 . .997$ & 3.688 & 1.165 & 0.014 & 0.011 & 0.21 \\
\hline Firm growth & 0.030 & 0.258 & 0.034 & 0.283 & -0.003 & 0.003 & 0.18 \\
\hline Capital intensity (ln) & 3.732 & 1.335 & 3.738 & 1.515 & -0.005 & 0.014 & 0.71 \\
\hline Flanders & 0.686 & 0.464 & 0.685 & 0.464 & 0.001 & 0.005 & 0.77 \\
\hline
\end{tabular}

$N=39,600$ firm-year observations (19,800 family firm observations and 19,800 nonfamily firm observations). s.d. standard deviation; s.e. standard error

\section{Dismissals}

\begin{tabular}{|c|c|c|c|c|c|c|c|}
\hline & \multicolumn{2}{|c|}{ Family firms } & \multicolumn{2}{|c|}{ Nonfamily firms } & \multicolumn{3}{|c|}{ Family firms - Nonfamily firms } \\
\hline & Mean & s.d. & Mean & s.d. & Contrast & s.e. & $p$ \\
\hline Dismissals & 0.041 & 0.064 & 0.042 & 0.065 & -0.001 & 0.001 & 0.18 \\
\hline \multicolumn{8}{|l|}{ Matching co-variates } \\
\hline Financial stewardship & 0.028 & 0.857 & 0.039 & 0.923 & -0.011 & 0.009 & 0.20 \\
\hline Compensation & 23.083 & 5.643 & 23.095 & 5.826 & -0.012 & 0.055 & 0.84 \\
\hline Male & 0.769 & 0.218 & 0.771 & 0.222 & -0.002 & 0.002 & 0.32 \\
\hline Blue collar & 0.596 & 0.297 & 0.603 & 0.310 & $-0.006^{*}$ & 0.003 & 0.02 \\
\hline Permanent contracts & 0.968 & 0.069 & 0.969 & 0.067 & -0.001 & 0.001 & 0.29 \\
\hline Firm age (ln) & 3.067 & 0.751 & 3.063 & 0.776 & 0.005 & 0.007 & 0.49 \\
\hline Firm size (ln) & 3.846 & 1.025 & 3.797 & 1.143 & $0.024 *$ & 0.010 & 0.02 \\
\hline Firm growth & 0.039 & 0.271 & 0.040 & 0.283 & -0.000 & 0.003 & 0.95 \\
\hline Capital intensity (ln) & 3.745 & 1.361 & 3.741 & 1.470 & 0.004 & 0.012 & 0.75 \\
\hline Flanders & 0.688 & 0.462 & 0.689 & 0.463 & -0.001 & 0.004 & 0.89 \\
\hline
\end{tabular}

$N=39,600$ firm-year observations (19,800 family firm observations and 19,800 nonfamily firm observations). s.d. standard deviation; s.e. standard error 
Voluntary turnover

\begin{tabular}{lrrrrrrc}
\hline & \multicolumn{2}{c}{ Family firms } & \multicolumn{2}{c}{ Nonfamily firms } & \multicolumn{2}{c}{ Family firms - Nonfamily firms } \\
\cline { 2 - 6 } & Mean & \multicolumn{1}{c}{ s.d. } & Mean & s.d. & \multicolumn{2}{c}{ Contrast } & s.e. \\
\hline Voluntary turnover & 0.155 & 0.172 & 0.145 & 0.170 & $0.009 * * *$ & 0.002 & 0.00 \\
Matching co-variates & & & & & & & \\
$\quad$ Financial stewardship & 0.028 & 0.857 & 0.034 & 0.938 & -0.006 & 0.009 & 0.50 \\
Compensation & 22.915 & 5.659 & 22.924 & 5.842 & -0.009 & 0.058 & 0.87 \\
Dismissals & 0.041 & 0.064 & 0.042 & 0.064 & -0.000 & 0.001 & 0.83 \\
Male & 0.785 & 0.218 & 0.782 & 0.221 & 0.001 & 0.002 & 0.46 \\
Blue collar & 0.603 & 0.297 & 0.611 & 0.304 & $-0.008 * *$ & 0.003 & 0.01 \\
Permanent contracts & 0.972 & 0.069 & 0.972 & 0.067 & 0.000 & 0.001 & 0.63 \\
Firm age (ln) & 3.066 & 0.751 & 3.060 & 0.789 & 0.006 & 0.007 & 0.44 \\
Firm size (ln) & 3.719 & 1.025 & 3.709 & 1.197 & 0.010 & 0.010 & 0.31 \\
Firm growth & 0.035 & 0.271 & 0.039 & 0.320 & -0.000 & 0.003 & 0.29 \\
Capital intensity (ln) & 3.745 & 1.361 & 3.734 & 1.486 & 0.011 & 0.014 & 0.43 \\
Flanders & 0.691 & 0.462 & 0.688 & 0.462 & 0.003 & 0.004 & 0.50 \\
\hline
\end{tabular}

$N=39,600$ firm-year observations (19,800 family firm observations and 19,800 nonfamily firm observations). s.d. standard deviation; s.e. standard error

\section{$\underline{\text { Labor Productivity }}$}

\begin{tabular}{|c|c|c|c|c|c|c|c|}
\hline & \multicolumn{2}{|c|}{ Family firms } & \multicolumn{2}{|c|}{ Nonfamily firms } & \multicolumn{3}{|c|}{ Family firms - Nonfamily firms } \\
\hline & Mean & s.d. & Mean & s.d. & Contrast & s.e. & $\mathrm{p}$ \\
\hline Labor Productivity & 65.799 & 45.629 & 68.057 & 47.065 & $-2.259 * * *$ & 0.466 & 0.00 \\
\hline \multicolumn{8}{|l|}{ Matching co-variates } \\
\hline Financial stewardship & 0.028 & 0.857 & 0.034 & 0.938 & -0.006 & 0.009 & 0.50 \\
\hline Compensation & 22.915 & 5.659 & 22.924 & 5.842 & -0.009 & 0.057 & 0.87 \\
\hline Dismissals & 0.041 & 0.064 & 0.042 & 0.064 & -0.000 & 0.001 & 0.83 \\
\hline Male & 0.784 & 0.204 & 0.784 & 0.204 & 0.001 & 0.002 & 0.73 \\
\hline Blue collar & 0.605 & 0.291 & 0.612 & 0.295 & $-0.007 * *$ & 0.003 & 0.01 \\
\hline Permanent contracts & 0.972 & 0.068 & 0.972 & 0.063 & 0.000 & 0.001 & 0.88 \\
\hline Firm age $(\ln )$ & 3.066 & 0.711 & 3.060 & 0.746 & 0.005 & 0.007 & 0.44 \\
\hline Firm size $(\ln )$ & 3.728 & 0.902 & 3.709 & 1.018 & $0.019+$ & 0.010 & 0.06 \\
\hline Firm growth & 0.032 & 0.271 & 0.034 & 0.280 & -0.002 & 0.003 & 0.53 \\
\hline Capital intensity (ln) & 3.741 & 1.361 & 3.742 & 1.479 & -0.001 & 0.014 & 0.96 \\
\hline Flanders & 0.692 & 0.462 & 0.690 & 0.463 & 0.001 & 0.004 & 0.77 \\
\hline
\end{tabular}

$N=39,600$ firm-year observations (19,800 family firm observations and 19,800 nonfamily firm observations). s.d. standard deviation; s.e. standard error 


\section{Restricted time period (2008-2014)}

$\underline{\text { Financial stewardship }}$

\begin{tabular}{|c|c|c|c|c|c|c|c|}
\hline & \multicolumn{2}{|c|}{ Family firms } & \multicolumn{2}{|c|}{ Nonfamily firms } & \multicolumn{3}{|c|}{ Family firms - Nonfamily firms } \\
\hline & Mean & s.d. & Mean & s.d. & Contrast & s.e. & $\mathrm{p}$ \\
\hline Financial stewardship & -0.113 & 0.850 & -0.155 & 0.926 & $0.041 * *$ & 0.014 & 0.00 \\
\hline Matching co-variates & & & & & & & \\
\hline Firm age $(\ln )$ & 3.295 & 0.590 & 3.296 & 0.660 & -0.000 & 0.010 & 0.96 \\
\hline Firm size $(\ln )$ & 3.906 & 0.799 & 3.896 & 0.867 & 0.009 & 0.013 & 0.48 \\
\hline Capital intensity $(\ln )$ & 3.813 & 1.280 & 3.786 & 1.469 & 0.027 & 0.022 & 0.22 \\
\hline Flanders & 0.679 & 0.467 & 0.677 & 0.468 & 0.002 & 0.008 & 0.82 \\
\hline
\end{tabular}

$N=15,474$ firm-year observations (7,737 family firm observations and 7,737 nonfamily firm observations). s.d. standard deviation; s.e. standard error

Compensation

\begin{tabular}{lccccccc}
\hline & \multicolumn{2}{c}{ Family firms } & \multicolumn{2}{c}{ Nonfamily firms } & \multicolumn{3}{c}{ Family firms - Nonfamily firms } \\
\cline { 2 - 8 } & Mean & s.d. & Mean & s.d. & Contrast & s.e. & p \\
\hline Compensation & 24.064 & 5.428 & 25.535 & 7.119 & -1.471 *** & 0.102 & 0.00 \\
Matching co-variates & & & & & & & \\
$\quad$ Financial stewardship & -0.113 & 0.850 & -0.113 & 0.915 & -0.001 & 0.014 & 0.97 \\
$\quad$ Off-site training & 0.119 & 0.252 & 0.126 & 0.264 & -0.007 & 0.004 & 0.10 \\
Dismissals & 0.038 & 0.057 & 0.039 & 0.058 & -0.001 & 0.001 & 0.46 \\
Male & 0.787 & 0.205 & 0.789 & 0.207 & -0.002 & 0.003 & 0.59 \\
Blue collar & 0.601 & 0.282 & 0.605 & 0.290 & -0.004 & 0.004 & 0.39 \\
Permanent contracts & 0.971 & 0.068 & 0.971 & 0.065 & 0.000 & 0.001 & 0.83 \\
Education & 0.162 & 0.223 & 0.157 & 0.215 & 0.005 & 0.003 & 0.13 \\
Firm age (ln) & 3.274 & 0.607 & 3.276 & 0.667 & -0.001 & 0.010 & 0.88 \\
Firm size (ln) & 3.918 & 0.805 & 3.900 & 0.887 & 0.018 & 0.013 & 0.18 \\
Firm growth & 0.011 & 0.141 & 0.014 & 0.169 & -0.003 & 0.002 & 0.17 \\
Capital intensity (ln) & 3.822 & 1.312 & 3.790 & 1.491 & 0.032 & 0.022 & 0.15 \\
Flanders & 0.686 & 0.464 & 0.685 & 0.465 & 0.001 & 0.007 & 0.88 \\
\hline
\end{tabular}

$N=16,522$ firm-year observations (8,261 family firm observations and 8,261 nonfamily firm observations). s.d. standard deviation; s.e. standard error

Off-Site Training

\begin{tabular}{|c|c|c|c|c|c|c|c|}
\hline & \multicolumn{2}{|c|}{ Family firms } & \multicolumn{2}{|c|}{ Nonfamily firms } & \multicolumn{3}{|c|}{ Family firms - Nonfamily firms } \\
\hline & Mean & s.d. & Mean & s.d. & Contrast & s.e. & $\mathrm{p}$ \\
\hline Off-site Training & 0.121 & 0.253 & 0.140 & 0.286 & $-0.019 * * *$ & 0.004 & 0.00 \\
\hline \multicolumn{8}{|l|}{ Matching co-variates } \\
\hline Financial stewardship & -0.113 & 0.850 & -0.120 & 0.901 & 0.007 & 0.014 & 0.62 \\
\hline Compensation & 24.117 & 5.618 & 24.104 & 5.781 & 0.013 & 0.090 & 0.89 \\
\hline Dismissals & 0.039 & 0.060 & 0.040 & 0.062 & -0.001 & 0.001 & 0.40 \\
\hline Male & 0.767 & 0.199 & 0.769 & 0.219 & -0.002 & 0.003 & 0.58 \\
\hline Blue collar & 0.589 & 0.287 & 0.595 & 0.301 & -0.005 & 0.005 & 0.26 \\
\hline Permanent contracts & 0.967 & 0.071 & 0.968 & 0.066 & -0.000 & 0.001 & 0.66 \\
\hline Education & 0.169 & 0.224 & 0.164 & 0.215 & 0.005 & 0.003 & 0.15 \\
\hline Firm age (ln) & 3.295 & 0.592 & 3.288 & 0.640 & 0.007 & 0.010 & 0.48 \\
\hline Firm size (ln) & 4.015 & 0.867 & 3.995 & 0.923 & 0.021 & 0.014 & 0.15 \\
\hline Firm growth & 0.010 & 0.171 & 0.012 & 0.186 & -0.002 & 0.002 & 0.31 \\
\hline Capital intensity (ln) & 3.830 & 1.392 & 3.817 & 1.500 & 0.013 & 0.023 & 0.55 \\
\hline Flanders & 0.683 & 0.465 & 0.680 & 0.465 & 0.003 & 0.007 & 0.66 \\
\hline
\end{tabular}


$\underline{\text { Dismissals }}$

\begin{tabular}{lccccccc}
\hline & \multicolumn{2}{c}{ Family firms } & \multicolumn{2}{c}{ Nonfamily firms } & \multicolumn{2}{c}{ Family firms - Nonfamily firms } \\
\cline { 2 - 7 } & Mean & s.d. & Mean & s.d. & Contrast & s.e. & p \\
\hline Dismissals & 0.039 & 0.057 & 0.041 & 0.061 & $-0.003 * *$ & 0.001 & 0.00 \\
Matching co-variates & & & & & & & \\
$\quad$ Financial stewardship & -0.116 & 0.854 & -0.111 & 0.884 & -0.005 & 0.014 & 0.73 \\
Compensation & 24.097 & 5.481 & 24.038 & 5.675 & 0.058 & 0.087 & 0.50 \\
Off-site training & 0.119 & 0.252 & 0.117 & 0.249 & 0.003 & 0.004 & 0.51 \\
Male & 0.787 & 0.205 & 0.788 & 0.206 & -0.001 & 0.003 & 0.69 \\
Blue collar & 0.601 & 0.282 & 0.607 & 0.287 & -0.006 & 0.004 & 0.17 \\
Permanent contracts & 0.971 & 0.068 & 0.972 & 0.065 & -0.001 & 0.001 & 0.62 \\
Education & 0.162 & 0.223 & 0.159 & 0.219 & 0.003 & 0.003 & 0.36 \\
Firm age (ln) & 3.274 & 0.607 & 3.272 & 0.665 & 0.002 & 0.010 & 0.82 \\
Firm size (ln) & 3.918 & 0.805 & 3.898 & 0.870 & 0.019 & 0.013 & 0.14 \\
Firm growth & 0.011 & 0.141 & 0.012 & 0.167 & -0.001 & 0.002 & 0.57 \\
Capital intensity (ln) & 3.822 & 1.312 & 3.796 & 1.435 & 0.025 & 0.021 & 0.24 \\
Flanders & 0.686 & 0.464 & 0.679 & 0.467 & 0.006 & 0.007 & 0.39 \\
\hline
\end{tabular}

$N=16,522$ firm-year observations (8,261 family firm observations and 8,261 nonfamily firm observations). s.d. standard deviation; s.e. standard error

Voluntary turnover

\begin{tabular}{|c|c|c|c|c|c|c|c|}
\hline & \multicolumn{2}{|c|}{ Family firms } & \multicolumn{2}{|c|}{ Nonfamily firms } & \multicolumn{3}{|c|}{ Family firms - Nonfamily firms } \\
\hline & Mean & s.d. & Mean & s.d. & Contrast & s.e. & $\mathrm{P}$ \\
\hline Voluntary turnover & 0.150 & 0.160 & 0.144 & 0.158 & $0.006^{*}$ & 0.003 & 0.03 \\
\hline \multicolumn{8}{|l|}{ Matching co-variates } \\
\hline Financial stewardship & -0.113 & 0.850 & -0.099 & 0.901 & -0.014 & 0.014 & 0.31 \\
\hline Compensation & 24.064 & 5.428 & 24.134 & 5.676 & -0.070 & 0.089 & 0.44 \\
\hline Off-Site Training & 0.121 & 0.253 & 0.122 & 0.258 & -0.001 & 0.004 & 0.73 \\
\hline Dismissals & 0.039 & 0.057 & 0.039 & 0.058 & -0.001 & 0.001 & 0.48 \\
\hline Male & 0.786 & 0.206 & 0.788 & 0.205 & -0.002 & 0.003 & 0.54 \\
\hline Blue collar & 0.599 & 0.282 & 0.603 & 0.291 & -0.005 & 0.005 & 0.29 \\
\hline Permanent contracts & 0.972 & 0.068 & 0.972 & 0.064 & -0.001 & 0.001 & 0.58 \\
\hline Education & 0.163 & 0.224 & 0.160 & 0.219 & 0.003 & 0.003 & 0.38 \\
\hline Firm age $(\ln )$ & 3.272 & 0.608 & 3.267 & 0.661 & 0.005 & 0.010 & 0.62 \\
\hline Firm size $(\ln )$ & 3.921 & 0.806 & 3.904 & 0.877 & 0.017 & 0.013 & 0.20 \\
\hline Firm growth & 0.011 & 0.141 & 0.015 & 0.177 & -0.004 & 0.003 & 0.15 \\
\hline Capital intensity (ln) & 3.813 & 1.308 & 3.808 & 1.519 & 0.005 & 0.022 & 0.83 \\
\hline Flanders & 0.686 & 0.464 & 0.688 & 0.464 & -0.002 & 0.007 & 0.79 \\
\hline
\end{tabular}

$N=16,360$ firm-year observations (8,180 family firm observations and 8,180 nonfamily firm observations). s.d. standard deviation; s.e. standard error

Labor Productivity

\begin{tabular}{|c|c|c|c|c|c|c|c|}
\hline & \multicolumn{2}{|c|}{ Family firms } & \multicolumn{2}{|c|}{ Nonfamily firms } & \multicolumn{3}{|c|}{ Family firms - Nonfamily firms } \\
\hline & Mean & s.d. & Mean & s.d. & Contrast & s.e. & $\mathrm{p}$ \\
\hline Labor Productivity & 72.031 & 43.659 & 74.017 & 44.368 & $-1.986 * * *$ & 0.708 & 0.00 \\
\hline \multicolumn{8}{|l|}{ Matching co-variates } \\
\hline Financial stewardship & -0.113 & 0.850 & -0.114 & 0.901 & 0.000 & 0.014 & 0.98 \\
\hline Compensation & 24.064 & 5.428 & 23.964 & 5.544 & 0.100 & 0.089 & 0.26 \\
\hline Off-Site Training & 0.121 & 0.253 & 0.123 & 0.255 & -0.002 & 0.004 & 0.59 \\
\hline Dismissals & 0.039 & 0.057 & 0.040 & 0.059 & -0.001 & 0.001 & 0.16 \\
\hline Male & 0.787 & 0.205 & 0.789 & 0.205 & -0.002 & 0.003 & 0.54 \\
\hline Blue collar & 0.601 & 0.282 & 0.605 & 0.291 & -0.004 & 0.004 & 0.41 \\
\hline Permanent contracts & 0.971 & 0.068 & 0.972 & 0.064 & -0.001 & 0.001 & 0.52 \\
\hline Education & 0.162 & 0.223 & 0.159 & 0.218 & 0.003 & 0.003 & 0.43 \\
\hline Firm age $(\ln )$ & 3.274 & 0.607 & 3.269 & 0.660 & 0.006 & 0.010 & 0.56 \\
\hline Firm size $(\ln )$ & 3.918 & 0.805 & 3.901 & 0.876 & 0.017 & 0.013 & 0.20 \\
\hline Firm growth & 0.011 & 0.141 & 0.014 & 0.176 & -0.004 & 0.002 & 0.13 \\
\hline Capital intensity (ln) & 3.822 & 1.312 & 3.809 & 1.517 & 0.013 & 0.022 & 0.57 \\
\hline Flanders & 0.686 & 0.464 & 0.687 & 0.464 & -0.002 & 0.007 & 0.80 \\
\hline
\end{tabular}

$\bar{N}=16,522$ firm-year observations (8,261 family firm observations and 8,261 nonfamily firm observations). s.d. standard deviation; s.e. standard error 
Jeroen Neckebrouck (jeroen.neckebrouck@ vlerick.com) is a doctoral student at Ghent University and Vlerick Business School, Belgium. He is ICM-FWO Fellow of the Research Fund - Flanders (FWO). His research focuses on private and family firms and the relationships between governance, strategic decision making and performance.

William Schulze (William.Schulze@Utah.edu) is a David Eccles Professor in the Department of Entrepreneurship and Strategy at the David Eccles School of Business at the University of Utah. He received his Ph.D. from the University of Colorado - Boulder. His research interests focus on the governance of private and closely held firms and new venture formation and growth.

Thomas Zellweger (thomas.zellweger@ unisg.ch) is Professor of Management at the University of St. Gallen, Switzerland. He received his Ph.D. from the University of St. Gallen. His research explores family firms, corporate governance and entrepreneurship. 